NBER WORKING PAPER SERIES

\title{
DOES THE PROFIT MOTIVE MAKE JACK NIMBLE? OWNERSHIP FORM AND THE EVOLUTION OF THE U.S. HOSPITAL INDUSTRY
}

\author{
Sujoy Chakravarty \\ Martin Gaynor \\ Steven Klepper \\ William B. Vogt \\ Working Paper 11705 \\ http://www.nber.org/papers/w11705
NATIONAL BUREAU OF ECONOMIC RESEARCH 1050 Massachusetts Avenue
Cambridge, MA 02138
October 2005

\begin{abstract}
We are greatly indebted to NBER for the permission of using the AHA Annual Survey, datasets. We would like to express our sincere thanks to Mohan Ramanujan and Jean Roth for their kind assistance. We would also like to thank Kristin Madison for access to her hospital system membership database. The views expressed herein are those of the author(s) and do not necessarily reflect the views of the National Bureau of Economic Research.

C2005 by Sujoy Chakravarty, Martin Gaynor, Steven Klepper, and William B. Vogt. All rights reserved. Short sections of text, not to exceed two paragraphs, may be quoted without explicit permission provided that full credit, including $(\odot)$ notice, is given to the source.
\end{abstract}


Does the Profit Motive Make Jack Nimble? Ownership Form and the Evolution of the U.S. Hospital Industry

Sujoy Chakravarty, Martin Gaynor, Steven Klepper, and William B. Vogt

NBER Working Paper No. 11705

October 2005

JEL No. I11, L11, L2, L3

\begin{abstract}
$\underline{\text { ABSTRACT }}$
We examine the evolving structure of the U.S. hospital industry since 1970, focusing on how ownership form influences entry and exit behavior. We develop theoretical predictions based on the model of Lakdawalla and Philipson, in which for-profit and not-for-profit hospitals differ regarding their objectives and costs of capital. The model predicts for-profits would be quicker to enter and exit than not-for-profits in response to changing market conditions. We test this hypothesis using data for all U.S. hospitals from 1984 through 2000. Examining annual and regional entry and exit rates, for-profit hospitals consistently have higher entry and exit rates than not-for-profits. Econometric modeling of entry and exit rates yields similar patterns. Estimates of an ordered probit model of entry indicate that entry is more responsive to demand changes for for-profit than not-forprofit hospitals. Estimates of a discrete hazard model for exit similarly indicate that negative demand shifts increase the probability of exit more for for-profits than not-for-profits. Finally, membership in a hospital chain significantly decreases the probability of exit for for-profits, but not not-forprofits.
\end{abstract}

Sujoy Chakravarty H. John Heinz III School of Public Policy and Management Carnegie Mellon University Pittsburgh, PA 15213-3890 sujoy@cmu.edu

Martin Gaynor H. John Heinz III School of Public Policy and Management Carnegie Mellon University Pittsburgh, PA 15213-3890 and NBER mgaynor@cmu.edu
Steven Klepper

Department of Social and Decision Sciences

Carnegie Mellon University

Pittsburgh, PA 15213-3890

sk3f@andrew.cmu.edu

William B. Vogt

H. John Heinz III School of

Public Policy and Management

Carnegie Mellon University

Pittsburgh, PA 15213-3890

and NBER

wilibear@andrew.cmu.edu 


\section{INTRODUCTION}

The hospital industry historically has been primarily composed of public and notfor-profit hospitals. But over the last three decades, the share of both types of hospitals has been failing as for-profits have taken over an increasing share of hospital activity (see Table 1). Whether this will usher in changes in the behavior and performance of hospitals depends on the extent to which for-profit hospitals behave differently than their not-for-profit counterparts. The purpose of this paper is to focus on one aspect of behavior that over the long run can have a considerable effect on an industry's structure: entry and exit decisions.

A number of studies have explored differences in the behavior of for-profit and not-for-profit hospitals. They have examined preferences for output (Newhouse,1970), costs and efficiency [Lewin et al. (1981), Becker and Sloan (1985), Vitaliano, Toren (1996), Zuckerman et al. (1994)], quality [Shortell and Hughes (1988), Keeler, (1992), Mark(1996), Sloan et. al (2001)], pricing and market power [Gruber (1994), Lynk (1995), Keeler (1999), Gaynor and Vogt (2003)], and provision of uncompensated care [(Norton and Staiger,1994), Mann et. al (1995)]. Many of these studies do not find significant differences in the behavior of for-profits and not-for-profits, and no consensus has yet emerged as to whether ownership type is a major factor behind observed differences when they do exist. A few studies have focused on the behavior of for-profits and notfor-profits in response to decreases in demand, and here differences do seem to emerge. Deily et al. (2000) find that less efficient hospitals were more likely to exit when privately owned, and Hansmann et al. (2002) find that over the period 1985-1994 forprofit hospitals adjusted their capacity more responsively to demand reductions than did public or not-for-profit hospitals.

The findings of Deily et al. (2000) and Hansmann et al. (2002) are suggestive that the exit behavior of for-profit and not-for-profit hospitals differs, and we explore this in considerable detail. We also analyze entry of for-profit and not-for-profit hospitals, which has not been previously explored. Theoretical work by Lakdawalla and Philipson (1998) demonstrates that if not-for-profits derive utility from greater quantity then they will behave as if they have lower effective costs than for-profits. This can provide a rationale for why not-for-profits appear to be less responsive to demand reductions than 
for-profits. The same logic suggests that not-for-profits would also be quicker to enter in response to demand growth, although we discuss how financial factors might impede the growth of not-for-profits and make them less responsive to entry opportunities. To explore how for-profit and not-for-profits respond to both growth and decline in demand, we examine entry and exit behavior of both types of hospitals at the county level in response to demand fluctuations.

We implement our analysis by constructing a panel data set for all hospitals over the period 1984-2000 that contains information for each hospital on its years of operation, location, ownership status, and system membership. We first examine annual entry and exit rates of for-profit and not-for-profits. These rates are positively correlated, suggesting that both types of hospitals responded similarly to market developments. But the annual entry and exit rates of for-profits were consistently higher than those for notfor-profits, suggesting that for-profits were more responsive to both growth and decline in demand.

We next analyze entry and exit rates at the county level, linking them to population changes and also market conditions relating to cost and profitability and to certificate-of-need regulations that vary across states. ${ }^{1}$ We also control for whether hospitals are part of systems. This might be expected to influence exit behavior based on the findings of Dunne, Roberts and Samuelson (1998) and Disney, Haskel, and Heden (2003) regarding differences in exit behavior of manufacturing plants that are and are not part of multi-plant firms. We also test whether entrants had higher rates of exit than incumbent firms, as is consistently found for manufacturing firms. Consistent with our findings about overall entry and exit rates, we find that entry as well as exit was more responsive to demand changes for for-profits than not-for-profits. System membership also influenced entry and exit rates. Unlike the manufacturing sector, however, entrants were not more likely to exit than older, incumbent firms.

The paper is organized as follows. Section II contains the economic model featuring the Lakdawalla and Philipson theory. It also discusses how the ability of notfor-profits to expand into growing markets might be constrained by their limited ability to raise capital. Section III presents the econometric model and Section IV describes the

\footnotetext{
${ }^{1}$ Certificate of Need regulations are state specific and control the entry and expansion of hospitals.
} 
data. Section V presents the results in three broad subsections. First, changes in the structure of the U.S. hospital industry over the last three decades are described. Next entry and exit at the national and regional level are analyzed. Then estimates of our econometric model are presented. Section VI contains a summary and conclusions.

\section{CONCEPTUAL MODEL}

Traditionally, not-for-profits are thought to derive utility from a number of factors in addition to profits. Candidates include the quantity or quality of the services they provide, care to the indigent, and physician revenue, among other factors (Newhouse, 1970; Pauly, 1978; Sloan, 2000). Lakdawalla and Philipson (1998) posit that not-forprofits care primarily about two factors: profit and the quantity of services provided. This implies a utility function for not-for-profits of $U(x, \pi)$, where $x$ denotes output and $\pi$ profit. Assuming hospitals choose a level of output that maximizes their utility, the firstorder condition for a maximum is:

$$
\frac{U_{x}}{U_{\pi}}=-\pi_{x} .
$$

Profits for a hospital are equal to revenue minus costs, both of which are a function of output:

$\pi=p(x) x-c(x)$.

Differentiating profits w.r.t. output gives

$$
\pi_{x}=p_{x} x+p-c_{x} .
$$

Combining (2) and (4), we get

$$
p_{x} x+p=c_{x}-\frac{U_{x}}{U_{\pi}} .
$$

The term on the right-hand-side of equation (5) is the effective marginal cost of a not-for-profit. It equals the traditional marginal cost of production $c_{x}$ minus the implicit value not-for-profits place on additional units of output. For-profit hospitals, in contrast, are assumed to care only about profits. Then $U_{x}$ equals 0 and the right-hand-side of (2) simplifies to $c_{x}$. Thus, in effect, not-for-profits have lower marginal costs than for-profits because of their preference for output. This could be attributed to not-for-profits having a goal of serving the community, with greater output the vehicle for providing greater 
service $^{2}$. An alternative rationale for the lower effective costs of not-for-profits is that they are less able or willing than for-profits at preventing their managers from indulging their preferences (at the expense of profits). The inability to discipline managers could arise due to the absence of residual claimants in the case of not-for-profits. For-profits, on the other hand, have stockholder representatives on the board of directors, who are the natural group to discipline managers.

If indeed not-for-profits have lower marginal costs than for-profits, then it is easy to see why for-profits would be the first to exit markets in which both for-profits and notfor-profits participate. The same logic suggests that not-for-profits would be the first to enter new markets that are growing - they will require a lower price than for-profits to enter and thus might be expected to enter before for-profits. ${ }^{3}$ Indeed, taken to its extreme, this logic questions why for-profit hospitals exist at all.

One factor that can help explain the existence of for-profits is capital. If not-forprofits indulge their preference for output, then they will earn lower profits than forprofits, and hence earn a lower return on investment. They will then be at a disadvantage in financing their operations unless they have preferential access to capital. Historically, this has been the case. Prior to 1970, not-for-profits raised a considerable amount of their capital from philanthropic sources, which provided them with an advantage. But contributions to hospitals peaked in 1965 at $\$ 2.1$ billion and by 1981 had fallen to $\$ 603$ million in constant dollars (Sloan et al, 1990). Not-for-profit hospitals also benefited from the federal Hill-Burton act, which subsidized not-for-profit and public hospital investment. The other main advantage of not-for-profits in raising capital stems from their ability to qualify as municipal borrowers. Lenders then do not have to pay federal, state, or local tax on interest received, enabling not-for-profit hospitals to issue bonds at lower interest rates than for-profits. Federal tax reform in 1986, however, eliminated institutional investors' deductions of carrying charges for holding tax exempt bonds, reducing the spread between taxable and tax exempt bond yields (Grossman et al., 1983). In addition, the General Accounting Office reported that by 1990 at least 17 states had

\footnotetext{
${ }^{2}$ Not-for-profit hospitals are often referred to as community hospitals, and many of them have the word community in their title.

${ }^{3}$ In the Lakdawalla-Phillipson model, the number of not-for-profits is fixed, thus in their model for-profits are more likely to enter growing markets.
} 
enacted or were considering legislation allowing not-for-profits favorable tax treatment only if they provided charity care (Hassan et al., 2000). Consequently, in recent years not-for-profits have found it increasingly costly to raise capital.

If not-for-profits have been constrained in their ability to raise capital, then it might be expected that for-profits would be more responsive to new opportunities for growth. Existing not-for-profits already have capital, and if the capital was raised at preferential rates then they might be expected to remain longer in declining markets than for-profits in order to indulge their preference for output. This suggests that for-profits might be more responsive both to increases and decreases in demand. They would be the first to enter growing markets and the first to exit declining markets.

Another factor that might bear on the responsiveness of hospitals to demand changes is whether they are part of hospital systems. Hospitals that are part of systems may have lower costs and greater access to capital (Levitz and Brooke, 1985; Carey, 2003; Cleverley, 1992). Lower costs would enable them to survive longer in declining markets and thus be less likely to exit, all else equal. Lower costs would also enable them to enter growing markets more quickly, which would be reinforced by their greater access to capital. This suggests that entrants would be more likely than exiters to be part of systems for both for-profit and not-for-profit hospitals.

\section{METHODS}

If all hospitals were identical other than regarding their ownership status, then Lakdawalla-Philipson hypothesis suggests that in markets in which both ownership forms coexist, for-profit hospitals will always be the marginal firm. Consequently, in response to shifts in demand, for-profits would always enter and exit before not-for-profits ${ }^{4}$. But in the presence of heterogeneity, high-cost for-profits might exit before lower-cost notfor-profits, and similarly not-for-profits might be quicker to capture a particular growth opportunity than for-profits. Accordingly, we test our hypothesis by comparing entry and exit rates of for-profit and not-for-profit hospitals.

We undertake three types of analyses. First, we describe broadly how the hospital industry has evolved in recent years. We focus on differences between for-profits and

\footnotetext{
${ }^{4}$ The theory of Lakdawalla and Philipson implies that there is no entry or exit by not-for-profits
} 
not-for-profits, entrants/exiters and incumbent firms, system members and non-members, and hospitals in different regions. We also consider the extent to which trends in the hospital industry conform to patterns in other sectors, particularly the manufacturing sector, which has been examined extensively using plant-level data.

Second, we conduct an econometric analysis of entry. We use an ordered probit model to test whether for-profit hospitals are more responsive to changes in the profitability of entry than not-for-profit hospitals. Hospital entries in each county between 1984 and 2000 are regressed on a measure of demand shift over the period and a number of control variables. We use changes in the elderly population as our measure of exogenous demand shifts. The elderly are heavy consumers of health care, so growth in the elderly population should be highly correlated with growth in the demand for hospital services. In most years, entry in a county is quite low and often zero. Accordingly, entry is coded in four levels-zero, one, two, or three or more. Separate analyses are conducted for for-profit and not-for-profit hospitals. We expect that the effect of demand growth on firm entry will be greater for for-profits.

Third, we conduct an econometric analysis of exit. First, we perform a difference-in-differences analysis of exit. We examine counties with only for-profit hospitals, counties with only not-for-profit hospitals, and counties with both types of hospitals. If for-profits are more likely to exit in response to decreases in demand, exit rates should be greater for for-profits both in the single ownership counties and in the mixed counties. Furthermore, in the mixed counties the difference between the exit rates of for-profits and not-for-profits should be magnified if for-profits are the marginal firm. Accordingly, we test whether the difference in exit rates for for-profit and not-for-profit hospitals is greater in mixed than single-ownership counties.

We also estimate a logit discrete hazard model of exit for each of the years 1985 to 2000, which allows us to control for other aspects of hospitals than their ownership status that might influence exit. The model takes the form:

$$
\ln \frac{P_{i j t}}{1-P_{i j t}}=X_{j t} \beta_{c}+X_{i t} \beta_{h},
$$

where $P_{i j t}$ is the probability of hospital i in county j exiting in year t, $X_{j t}$ contains the characteristics of county $\mathrm{j}$ at time $\mathrm{t}$, and $X_{i t}$ contains the characteristics of hospital i at 
time t. Our key measure of interest in $X_{j t}$ is the shift in demand, again proxied by the log change in elderly population. As in the ordered probit analysis, we estimate the model separately for for-profit and not-for-profit hospitals. Because we are interested in testing whether for-profit hospitals are marginal, we examine only those counties in which both for-profit and not-for-profit hospitals operate. If for-profit hospitals are more sensitive to changing demand conditions, we expect the marginal effect of the demand shift variable to be greater for for-profit than not-for-profit hospitals.

We also estimate one additional model of exit for counties and years in which at least one exit occurred and for-profit, not-for-profit, and government hospitals were all operating in the county for that year. For each such county-year, we analyze the probability that the exit is by a for-profit, not-for-profit, or government hospital, and how these probabilities vary according to changes in demand. If for-profits are more sensitive to demand conditions, then exiters should be more likely to be for-profits in counties in which demand is falling than in counties in which it is increasing. We model the probability that an exit is by a for-profit (in a market containing all three ownership types) as:

$$
P_{F P}=\frac{\exp \left(X_{j t} \beta_{F P}\right)}{\exp \left(X_{j t} \beta_{G V T}\right)+\exp \left(X_{j t} \beta_{F P}\right)+\exp \left(X_{j t} \beta_{N F P}\right)},
$$

where $P_{F P}$ is the probability of a for-profit exit $\left(P_{N F P}\right.$ and $P_{G V T}$ are the analogous probabilities for not-for-profits and government hospital exits respectively), $X_{j t}$ are characteristics of county $\mathrm{j}$ at time $\mathrm{t}$, and $\beta_{F P}, \beta N_{F P}$, and $\beta_{G V T}$ are coefficients for the respective three types of hospitals. We perform similar analyses for not-for-profit and government hospitals.

\section{DATA}

\section{A. Sources}

We use data from three sources. First, we use data on U.S. hospital characteristics collected in an annual survey by the American Hospital Association (AHA). Some of this information that we use comprises bed size, inpatient days, length of stay, services 
offered, system membership, ownership type, and location. The data are available in electronic form from the National Bureau of Economic Research, which provides complete information for 1985 to 2000 and partial information for even-numbered years from 1970 to 1984. We have entry exit information only from 1984-2000 and system membership information from 1985. Thus entry exit analysis is over 1984-2000. (The econometric analysis of exit, which requires system membership information, is from 1985). Second, we use the Area Resource File (ARF), and U.S.Census data which provide measures at the county level for population, elderly population and per-capita income. Third, we use data on hospital system membership compiled from multiple sources by Professors Daniel Kessler and Kristin Madison (Madison, 2004). While the AHA survey contains extensive year-by-year information on hospital system membership status, it contains some internal inconsistencies and also does not conform to the information in other sources containing merger acquisition data, such as Modern Healthcare, a hospital trade publication. We use a corrected system database created by Kessler and Madison for the years 1985-1998. For the years 1999 and 2000 we modified and extended their algorithm to create our own system membership database. We also use hospital wage index data from Centers for Medicare and Medicaid Services, and information on certificate of need laws from American Health Planning Association.

\section{B. Market Definition}

The product market we analyze is all short term hospital services. Our sample comprises all hospitals over the years 1970-2000 serving this product market. To meet our market definition a hospital must:

- List one of the following as its primary service offered: (1) general medical/surgical services; (2) obstetrics/gynecology; (3) eye-ear-nose-throat; (4) rehabilitation; or (5) all four of these categories for treatment of children

- Have an average length of stay below thirty days, and if it has a long-term-care unit then that unit should account for a minority of its admissions.

- Not be a federal hospital.

Because the market for hospital services is local and much of the data we use are organized at the county level, we use the county as our geographic unit of analysis. After eliminating counties in Alaska and Hawaii, our final sample comprises 3,070 counties. 


\section{RESULTS}

\section{A. Descriptive Analysis}

\section{Industry Structure across Ownership Types}

Table 1 lists the annual number of total and public, not-for-profit, and for-profit hospitals from 1970 to 2001. The total number of hospitals fell steadily, and by 2001 there were $13 \%$ less hospitals than in 1970. Much of this decline is accounted for by public hospitals. From 1978 to 2001 both the total number of hospitals, and the number of public hospitals fell every year, and there were 29\% less public hospitals in 2001 than 1970. The number of not-for-profit hospitals also declined by 10\% from 1970 to 2001. In contrast, the number of for-profit hospitals increased by 7\% from 1970 to 2001. Table 2 further illustrates the rise of the for-profit sector. In contrast to public and not-for-profit hospitals, for-profit hospitals have experienced growth in establishments, capacity, and output and have increased their share of all three measures since 1970.

The US hospital industry has experienced substantial consolidation in recent years, including a considerable increase in the proportion of hospitals that are part of multi-hospital systems. Figure 2 indicates that since 1985 over $80 \%$ of for-profit hospitals are part of systems, and the trend has been rising over time. System membership for not-for-profits is lower, around $40 \%$ as of 1985 , but it too has been growing, and by 2000 59\% of not-for-profit hospitals were part of systems. Figure 1 indicates that the average for-profit system contains three times as many hospitals as the average not-for-profit system.

Figure 2 reports the proportions of for-profit and not-for-profit entrants and exiters that are system members. We predicted a larger percentage of entrants than exiters would be system members. Consistent with this prediction, the percentage of entrants that are system members is $67 \%$ for for-profits and $62 \%$ for not-for-profits whereas only $42 \%$ and $47 \%$ of for-profit and not-for-profit exiters respectively are system 
members. The difference for for-profits is significant at the .01 level whereas the not-forprofit difference is not significant at conventional levels. ${ }^{5}$ Among the for-profit entrants that were part of systems, 36\% entered markets already containing members of the same hospital system. The comparable percentage for not-for-profit hospitals was much higher at $61 \%$.

Figure 3 examines mean bed sizes across entrants, exiters, and incumbents for various ownership types. Not-for-profit hospitals are larger than for-profit hospitals. They have an average of 188 beds versus 132 beds for for-profits. Not surprisingly, entrants and exiters are smaller than incumbents, and differences in their sizes according to ownership type are smaller. Among entrants, the average bed size of not-for-profits is 63 versus 59 for for-profits, and among exiters the respective values are 92 and 76 . The latter difference for exiters was significant at the .05 level whereas the difference for entrants was not.

\section{Entry and Exit at the National and Regional Levels}

Table 3 indicates that over the period 1984-2000, annual entry and exit rates were 1.5\% and $1.3 \%$ higher for for-profit than not-for-profit hospitals. Figure 4 indicates that the entry rates of for-profit and not-for-profits varied similarly over time. In 10 of 15 years they moved together and had a correlation coefficient of 0.5. Similarly, exit rates of for-profits and not-for-profits varied together. In 9 of 15 years they moved in the same direction and had a correlation coefficient of 0.6. This suggests that both for-profits and not-for-profits react similarly to changing market conditions, although the degree of reaction is uniformly smaller for not-for-profits.

In manufacturing industries, entrants typically have higher exit rates than incumbent firms (Dunne, Roberts, and Samuelson, 1988). Since for-profits have higher entry rates than not-for-profits, their higher exit rate could merely be due to hospital entrants having a higher exit rate than incumbent hospitals. To check this, Table 4 reports the proportion of entrants and incumbents as of 1984 that exited by the year 2000 separately for public, not-for-profit, and for-profit hospitals. There was no difference in these exit rates for public and not-for-profits. In contrast, for for-profits, the exit rate was

\footnotetext{
${ }^{5}$ The difference existed at $10 \%$ level however, indicated that some of the advantages of system membership made a difference in terms of not-for-profit survivability also
} 
actually higher for incumbents than exiters. This suggests that the higher exit rate of forprofits than not-for-profits was not driven by the higher entry rate of for-profits. It is a strikingly different pattern than has been observed in manufacturing industries.

We suspect this difference between the hospital and manufacturing industries reflects the local character of hospital services. Many manufacturing firms service national markets, whereas hospitals have to be located close to their consumer base. Over the eighties and ninties,, population shifted from central cities to suburbs and from the Northeast to the West and South. Consequently, incumbents tended to be located in declining markets, whereas entrants were located in growing markets. If for-profits were more likely to enter in response to growth opportunities, then for-profit entrants were especially likely to be located in growth markets. This could explain why the difference in the exit rates of incumbents and entrants was particularly pronounced for the forprofits and why these patterns were so different from the manufacturing sector.

Table 5 disaggregates the data on number of hospitals, entry, and exiters by ownership type into the nine Census divisions. In all regions except New England, forprofits have higher entry and exit rates than not-for-profits. Almost half the total entries in the for-profit sector from 1984 to 2000 were in the West South Central region, which also experienced the highest number of exits. ${ }^{6}$ The largest increase in the number of forprofit establishments occurred in the Mountain region, which experienced the highest regional growth in the overall and elderly populations of 50\% and $90 \%$ respectively. New England, Middle Atlantic and East North Central had some of the lowest increases in total and elderly population among the census divisions. They also had the lowest levels of for-profit entries. The muted for-profit entry in the Pacific region, in spite of high population growth, was probably due to the prevalence of the managed care industry.

The correlation coefficient between number of for-profit entrants and exiters across census regions is 0.9 . Since this is not due to exiting entrants, the high correlation is likely attributable to population shifts within the same census region. For-profit marginality predicts that for-profits would follow demand shifts to a greater degree than not-for-profits and thus would experience a higher correlation between entry and exit

\footnotetext{
${ }^{6}$ West South Central comprises the states of Arkansas, Louisiana, Oklahoma, Texas
} 
than not-for-profits. Interestingly, the correlation between entry and exit rates for not-forprofits is almost negligible at 0.08 .

\section{B. Econometric Analysis of Entry}

The conceptual model predicts that for-profit firms should be more nimble in their response to changing market circumstances. Following a positive demand shift, forprofit should disproportionately enter, and following a negative demand shift, for-profit firms should disproportionately exit. To test this prediction, we need a measure of demand shift. Measures of quantity are obviously endogenous. Given the local nature of the hospital market, a natural proxy for demand shift is the change in the local population. To analyze the primary determinants of demand shifts, we estimated a cross sectional regression for changes in local hospital capacity. The dependent variable is changes in log hospital beds ${ }^{7}$ at the Health Service Area (HSA) level over the period 1980 to $2000 .^{8}$ Table 6 reports the estimated effects of the explanatory variables in the regression. The strongest predictor of changes in hospital capacity is the change in the elderly population. This is to be expected given that about $60 \%$ of hospital services is delivered to the elderly, the elderly have been growing as a proportion of the population, and there has been a significant geographic reallocation of the elderly population in recent years. Accordingly, we use log change in elderly population as our primary measure of demand shift.

Table 8 reports estimates from the ordered probit analysis of for-profit and notfor-profit entry at the county level. ${ }^{9}$ Both types of hospital entry are positively and significantly related to log of total population in 1980 and log change in elderly population over 1980-2000. States with certificate of need (CON) laws regulate hospital entry to avoid overbedding and duplication of services. Using data from the American Health Planning Association, we included a dummy for states with certificate of need

\footnotetext{
${ }^{7}$ The correlations between capacity and other quantity measures such as admissions and days are all greater than 0.9

${ }^{8}$ HSA is a geographic area consisting of one or more contiguous counties, previously designated by the U.S. Department of Health and Human Services for health planning on a regional basis

${ }^{9}$ We examined the sensitivity of these results to the geographic market definition and the choice of demand proxy. We replicated all of the estimations reported here for a different geographic market definition, the HSA. The results were qualitatively the same when it came to entry. Exit results however, were sensitive to the choice of geographic markets. We examined the effects of using levels and growth for the total population instead of the elderly population as demand proxies. The results were not sensitive to the use of these different demand proxies.
} 
laws (CON), but this dummy did not have a significant effect on entry. Per capita income growth has a positive but insignificant effect on not-for-profit entry, but a negative and marginally significant effect on for-profit entry. This is opposite of what we would have expected for for-profits. Both for-profit and not-for-profit entry are negatively related to hospital wages, which comprise a major component of hospital costs ${ }^{10}$.

The main prediction of the conceptual model is that for-profits will be more responsive to changes in demand than not-for-profits. Consistent with this prediction, the estimated coefficient of the log change in the elderly population is 1.14 for for-profits and 0.39 for not-for-profits, and this difference is significant at $5 \%$ level. Since the ordered probit model is non-linear, it is more appropriate to look at the marginal effect of the demand shift on the expected number of entries. Similar to the coefficient estimates, the marginal effect of the log change in the elderly population is almost three times larger for for-profits than not-for-profits. If elderly population in the average county in the year 2000 was $1 \%$ above its existing level, our estimates imply that expected for-profit hospital entry would have been higher by $3.3 \%$ and expected not-for-profit hospital entry by $1.1 \%$

\section{Econometric Analysis of Exit}

Earlier we reported that for-profits generally had higher annual exit rates than notfor-profits, which is consistent with for-profits being the marginal firms. The conceptual model also implies that the difference between for-profit and not-for-profit exit rates should be more pronounced in markets where both ownership types are present. To understand why, consider a market with two hospitals that experiences a negative demand shift sufficient to force one of the hospitals to exit. In a market with two forprofit (not-for-profit) hospitals, the exiting firm must be a for-profit (not-for-profit). Thus, in uniform ownership markets, the exit rates for the two types are the same, 50\%. But in a market with one for-profit and one not-for-profit, if the for-profit is the marginal firm, then it will be the exiter. Therefore, in the mixed market the for-profit exit rate is $100 \%$ and the not-for-profit exit rate is $0 \%$.

\footnotetext{
${ }^{10}$ A hospital wage index is included in the regression (www.cms.gov). However, it is imperfectly measured. Wage indices are available only at the MSA level. For non-MSA areas, every state has a single rural wage index covering every non-MSA county. Due to changes in MSA definition, we take the wage indices over 1990-2000. Per capita income change is over 1980 and 2000. However, the correlation between base period wage index and per capita income is 0.53
} 
Obviously, because hospitals are heterogeneous we will not see such a dramatic difference, but this does suggest an estimation method. We can estimate the marginality of for-profit hospitals by taking the difference between for-profit and not-for-profit exit rates in mixed ownership markets and subtracting the difference between for-profit and not-for-profit exit rates in uniform ownership markets. If for-profits are marginal, this measure should be positive.

We tabulate exit rates by ownership type, demand growth, and uniform vs. mixed ownership markets in Tables 9 and 10. Table 9 breaks counties into four groups according to the quartile of overall population growth while Table 10 breaks counties into four groups according to the quartile of elderly population growth. Within each of these four groups, the counties are further subdivided into counties with for-profit but without not-for-profit hospitals (“only for-profit”), counties with not-for-profit but without forprofit hospitals ("only not-for-profit"), and counties with both for-profit and not-forprofit hospitals. ${ }^{11}$ For each of these twelve sets of counties we tabulate exit rates for both for-profit and not-for-profit hospitals. For example, Table 9 indicates that for counties in the lowest population growth quartile for which both for-profit and not-for-profit hospitals are present, exit rates were $0.46 \%$ for for-profits and $0.21 \%$ for not-for-profits.

The final column of the tables present the "difference in differences" estimates of the marginality of for-profit firms. For example, the entry in the difference column for Quartile 1 of Table 9 is calculated as $0.08=(0.46-0.21)-(0.31-0.14)$. This estimate is positive in all eight cases in the two tables, with five of the eight differences significant at conventional levels. Consistent with the theory, for-profit hospitals are not only more likely to exit,: they are especially more likely to exit when they are in mixed ownership markets.

The model further predicts that in markets with both for-profits and not-forprofits, exit is more sensitive to demand shifts for for-profits than not-for-profits. To test this prediction, we use the logistic discrete hazard model described earlier. Means and standard deviations for the variables used in the hazard model are reported in Table 11. Only county-years in which both for-profits and not-for-profits are considered. Separate hazard equations were estimated for the for-profits and not-for-profits. Estimates are

${ }^{11}$ Counties without either for-profit or not-for-profit hospitals are omitted 
reported in Table 12 for the marginal effects of county and hospital characteristics on the probability of exit for each group of hospitals.

A comparison of coefficient estimates from the two logistic regressions reveals that lower growth of the elderly population increases the probability of exit for both forprofit and not-for-profit hospitals. However, the estimated effect for for-profits of -0.017 is more than twice as large as the estimated effect for not-for-profits of -0.008 , as forprofit marginality would predict. System membership significantly decreases the probability of for-profit exit but does not affect the probability of not-for-profit exit. The effect of hospital wages is almost twice as large for for-profits than not-for-profits. For both groups, the existence of a certificate of need law does not have a significant effect on the probability of exit.

It is possible that the difference in for-profit and not-for-profit responsiveness reported in Table 12 is due to differences in the distribution of characteristics among hospitals rather than the propensity to exit. To address this, we take the estimates from Table 12 and apply them "out of sample” to the dataset for the opposite ownership type. The results of this exercise are reported in Table 13. If we take the estimates for the forprofit exit model and apply them to the data for the not-for-profit hospitals, we obtain an average exit probability of 0.037 and a marginal effect of the demand shift variable on exit of -0.043. Applying the not-for-profit model to this same not-for-profit data yields an average exit probability of 0.008 with a marginal effect of -0.01 . So, standardizing on the not-for-profit dataset, the marginal effect of a shift in demand on the exit rate is more than four times larger for for-profits than not-for-profits. The difference between forprofit and not-for-profit responsiveness to demand shifts remains whether we standardize on the for-profit data, the not-for-profit data, or a dataset pooling the two.

Our tests focus only on differences between for-profit and not-for-profit hospitals. To see whether the differential response is affected by the presence of a public hospital in a county, we incorporate public hospitals into our analysis. Three sets of coefficient parameter estimates, one for each type of hospital ownership, are presented in Table 14. Our main conclusions are robust to the presence of public hospitals in our model. High growth in elderly population, system membership, and low wage growth all significantly decrease the probability of for-profit exit. 
In our final analysis, we consider county-years in which an exit occurred and in which for-profit, not-for-profit, and public hospitals were all present. We employ a multinomial logit model in order to analyze the probability of these exits being of a forprofit, not-for-profit, or public hospital. The conceptual model predicts that for-profits will have the highest exit rate and that the probability of the exit being for-profit (relative to the other two forms) will be decreasing in demand shifters. The coefficient estimates of the model are presented in Table 15. The probability that a given exiting hospital will be for-profit (in markets containing all three types) is over 70\%. This probability is very responsive to the demand shift variable: in markets with growing elderly population, the probability that an exiting hospital is for-profit is dramatically reduced (the marginal effect of log elderly population growth on the probability of for-profit status is -0.52 , $\mathrm{p}<0.05)$. Existence of a certificate of need law also reduces the probability of for-profit exit at $10 \%$ level. Finally, the probability that the exit is not-for-profit is higher for high elderly population growth markets $(\mathrm{p}<0.1)$.

\section{SUMMARY AND CONCLUSIONS}

Our objective in this paper has been to examine the evolving structure of the U.S. hospital industry, in particular the ways in which ownership form influences entry and exit behavior. We test whether for-profits are the marginal firms in the hospital industry regarding both entry and exit. Our findings support this hypothesis. For-profits have higher entry rates than not-for-profits, and for-profit entry rates are more sensitive to demand shifts than not-for-profit. Furthermore, for-profits have higher exit rates than not-for-profit firms, and for-profit exit rates are more sensitive to demand shifts than notfor-profits. Finally, the difference between for-profit and not-for-profit exit rates is greater in markets in which both ownership types are present. All these results are consistent with the theory of for-profit marginality. We thus find evidence that there are significant differences between for-profits and not-for-profits in responsiveness to demand and that this affects the way that hospital market structure has evolved in the U.S. 


\section{References}

American Health Planning Association Website. www.ahpanet.org/National_directory.htm

Becker ER, Sloan FA. Hospital ownership and performance. Economic Inquiry 1985;

23(1): 21-36.

Carey K. Hospital cost efficiency and system membership. Inquiry 2003; 40:25-38.

Centers for Medicare and Medicaid Services Website. www.cms.hhs.gov

Cleverly WO. Financial and operating performance of systems: voluntary versus investor owned. Topics in Health Care Financing 1992; 18(4): 63-73.

Deily ME , McKay NL, Dorner FH. Exit and inefficiency: the effects of ownership type. Journal of Human Resources 2000; 35(4): 734-47.

Disney R, Haskel J, Heden Y. Entry exit and establishment survival in UK manufacturing. Journal of Industrial Economics 2003; 1:91-112.

Dunne T, Roberts MJ, L Samuelson. Patterns of firm entry and exit in U.S. manufacturing industries. Rand Journal of Economics 1988; 19(4): 495-515.

Gaynor M, Vogt WB. Competition among hospitals. Rand Journal of Economics 2003; 34(4):764-785.

Grossman M, Goldman F, Nesbitt SW, Mobilia P. Determinants of Interest Rates on TaxExempt Hospital Bonds. Journal of Health Economics 1993; 12(4): 385-410.

Gruber J. The effects of competitive pressure on charity-hospital response to price shopping in California. Journal of Health Economics 1994; 13(2):183-212.

Hassan M, Wedig G, Morrisey MA. Charity care by non-profit hospitals: The Price of tax-exempt Debt. International Journal of the Economics of Business 2000; 7(1): 47-62.

Hansmann H, Kessler D, McClellan M. Ownership form and trapped capital in the hospital industry. NBER Working Paper 8989. 
Keeler EB, Rubenstein LV, Kahn KL, Draper D, Harrison ER, McGinty MJ, Rogers WH, Brook RH. Hospital characteristics and quality of care. Journal of American Medical Association 1992; 268(13): 1709-14..

Keeler EB, Melnick G, Zwanziger J. The changing effects of competition on non-profit and for-profit hospital pricing behavior. Journal of Health Economics 1999; 18(1): 69-86.

Lakdawalla D, Philipson T. Nonprofit production and competition. NBER Working Paper 1998: 6377.

Levitz GS, Brooke PP Jr. Independent versus System Affiliated Hospitals: A comparative analysis of financial performance, cost and productivity. Health Services Research 1985; 20(3) :315-339.

Lewin LS, Derzon RA, Margulies R. Investor-owned and nonprofits differ in economic performance. Hospitals 1981; 55:52-60.

Lynk WJ. Nonprofit hospital mergers and exercise of market power. Journal of Law and Economics 1995; 38(2): 437-461.

Mann J, Melnick G, Bamezai A, Zwanziger J. Uncompensated care, hospitals responses to fiscal pressure. Health Affairs 1995; 14:263-270.

Madison K. Multihospital system membership and patient treatments, expenditures, and outcomes. Health Services Research 2004; 39:749-770.

Mark TL. Psychiatric hospital ownership and performance: do nonprofit organizations offer advantages in markets characterized by asymmetric information? Journal of Human Resources 1996; 31(3):631-649.

Newhouse J.P. Towards a theory of non-profit institutions: An economic model of a hospital. American Economic Review 1970; 60(1):64-74.

Norton EC, Staiger D. How hospital ownership affects access to care for the uninsured. Rand Journal of Economics 1994; 25(1):171-185.

Pauly M, Redisch M. The not-for-profit hospital as a physician's cooperative. American Economic Review 1973; 63: 87-99.

Shortell SM, Hughes EFX. The effect of regulation, competition, and ownership on mortality rates among hospital inpatients. New England Journal of Medicine 1988; 318(17): 1100-1107. 
Sloan FA, Hoerger T, Morrisey M, Hassan M. The demise of hospital philanthropy. Economic Inquiry 1990; 28: 725-743.

Sloan F, Picone G, Taylor D, Chou SY. Hospital ownership and cost and quality of care: is there a dime's worth of difference? Journal of Health Economics 2001; 20(1):1-21.

Sloan FA. Not-for-profit ownership and hospital Behavior. In Handbook of Health Economics, Vol 1, Culyer AJ, Newhouse JP (eds). Elsevier, 2000; 1141-1174.

Vitaliano DF, Toren M 1996. Hospital costs and efficiency in a regime of stringent regulation. Eastern Economic Journal 1996; 22(2):161-175.

Zuckerman S, Hadley J, Iezzoni L. measuring hospital efficiency with frontier cost functions. Journal of Health Economics 1994; 13(3):255-80. 
Figure : 1

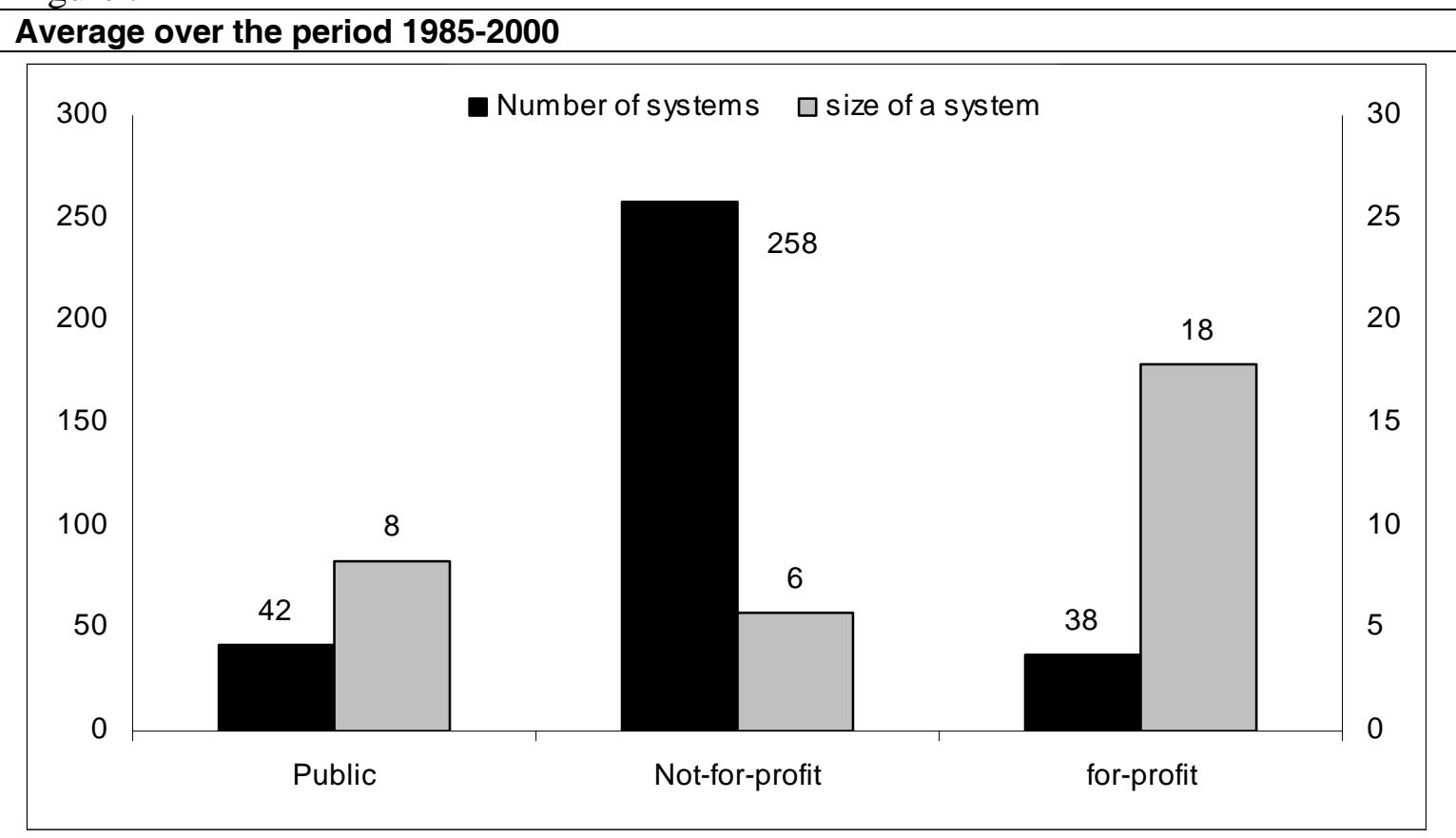

Note: Size of a system is measured by the number of establishments in that system; plotted along the secondary axis 
Figure : 2

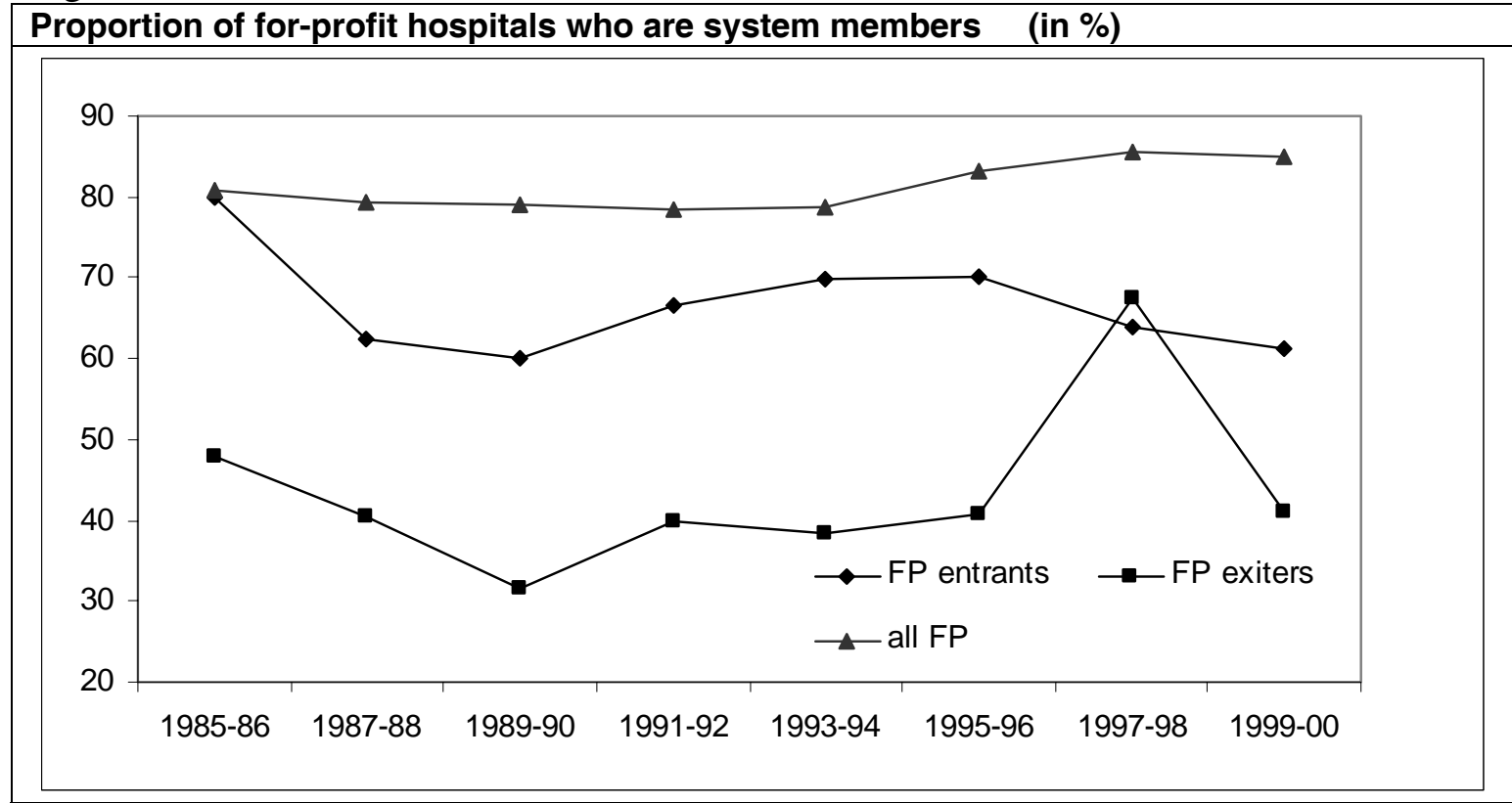

Note : The 95\% confidence interval for difference between entrant proportion and exiter proportion is $(13.8,36.7)$

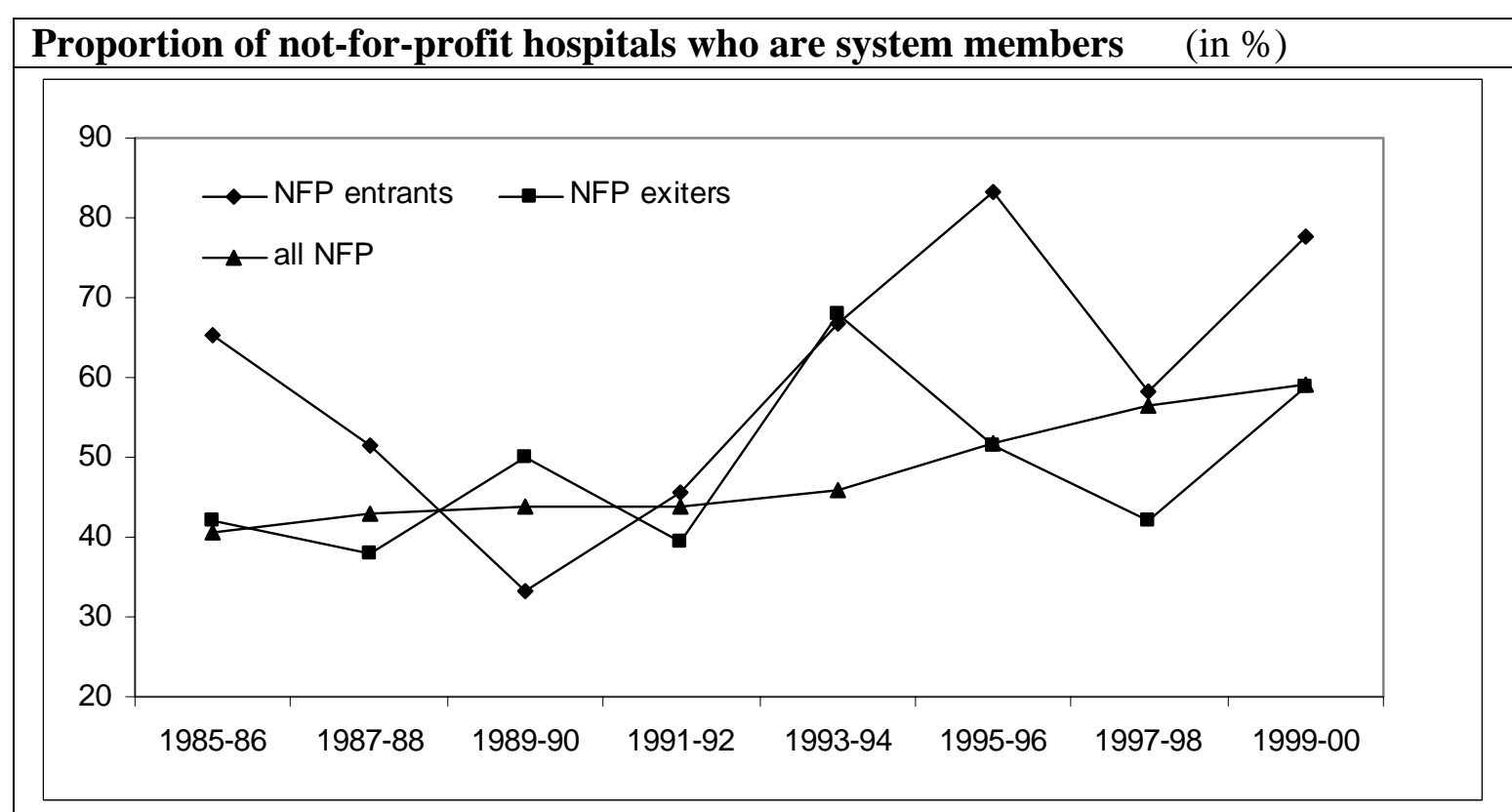

Note : The 95\% confidence interval for difference between entrant proportion and exiter proportion is $(-0.4,26.5)$ 


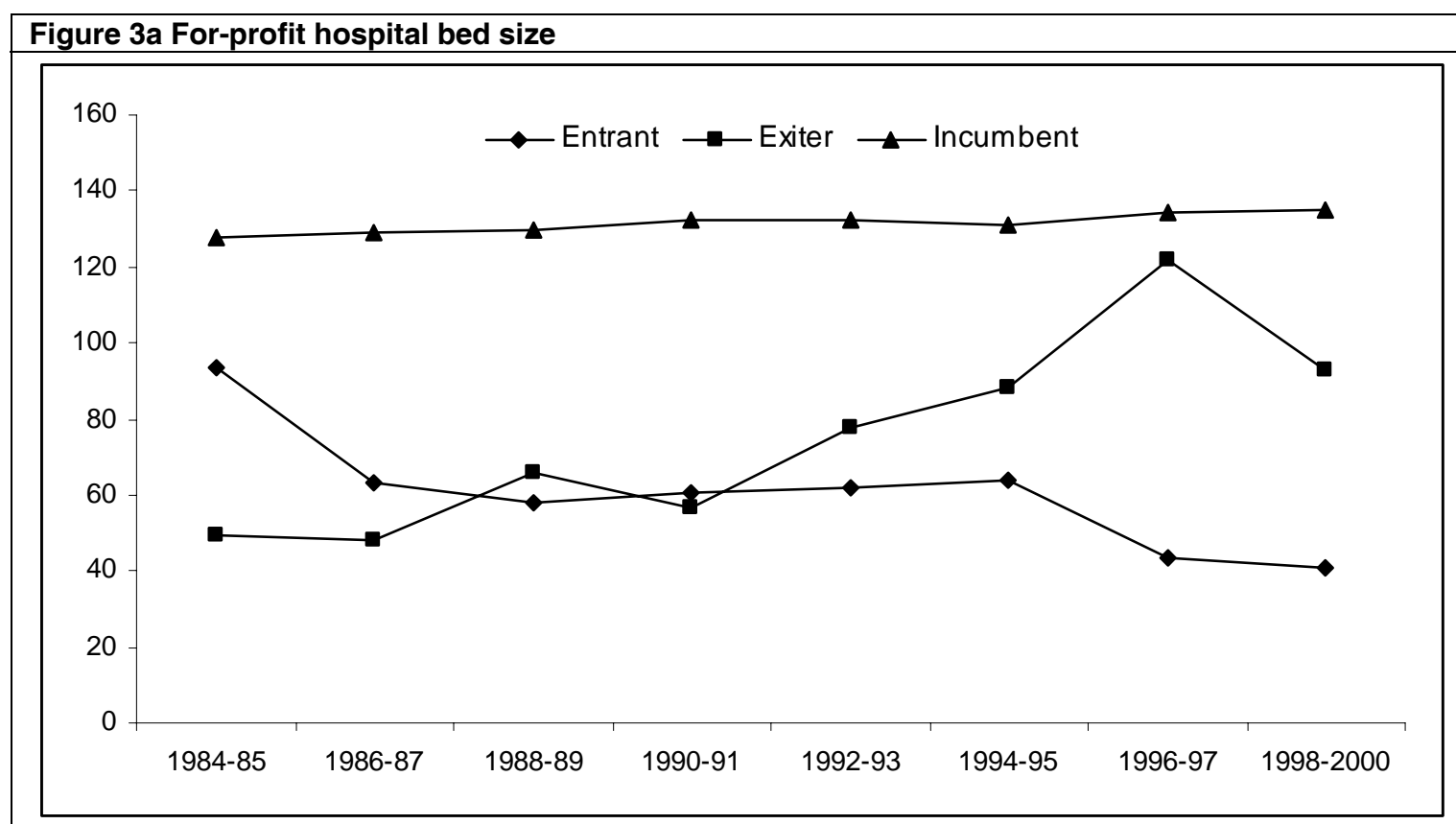

Figure 3b Not-for-profit hospital bed size

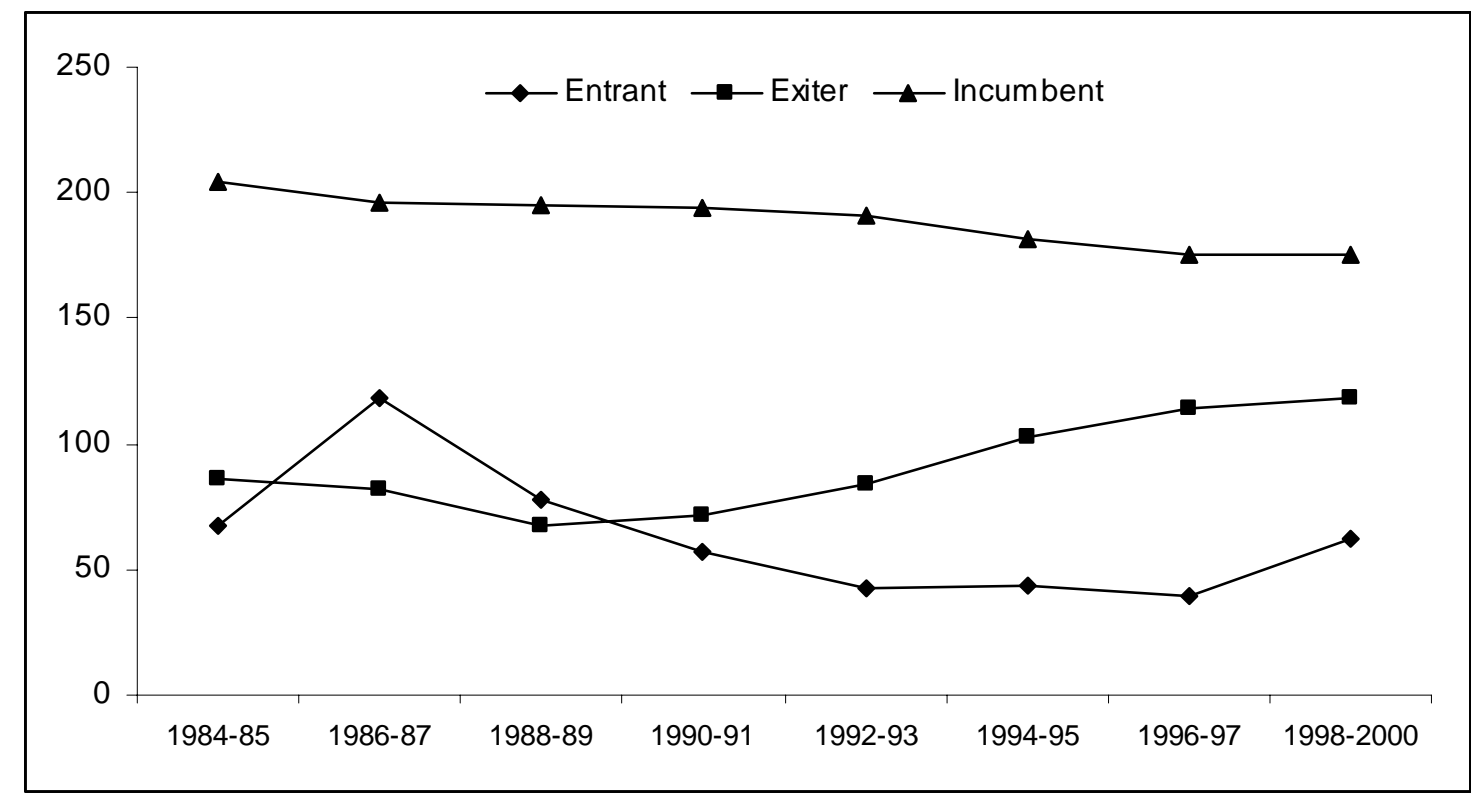




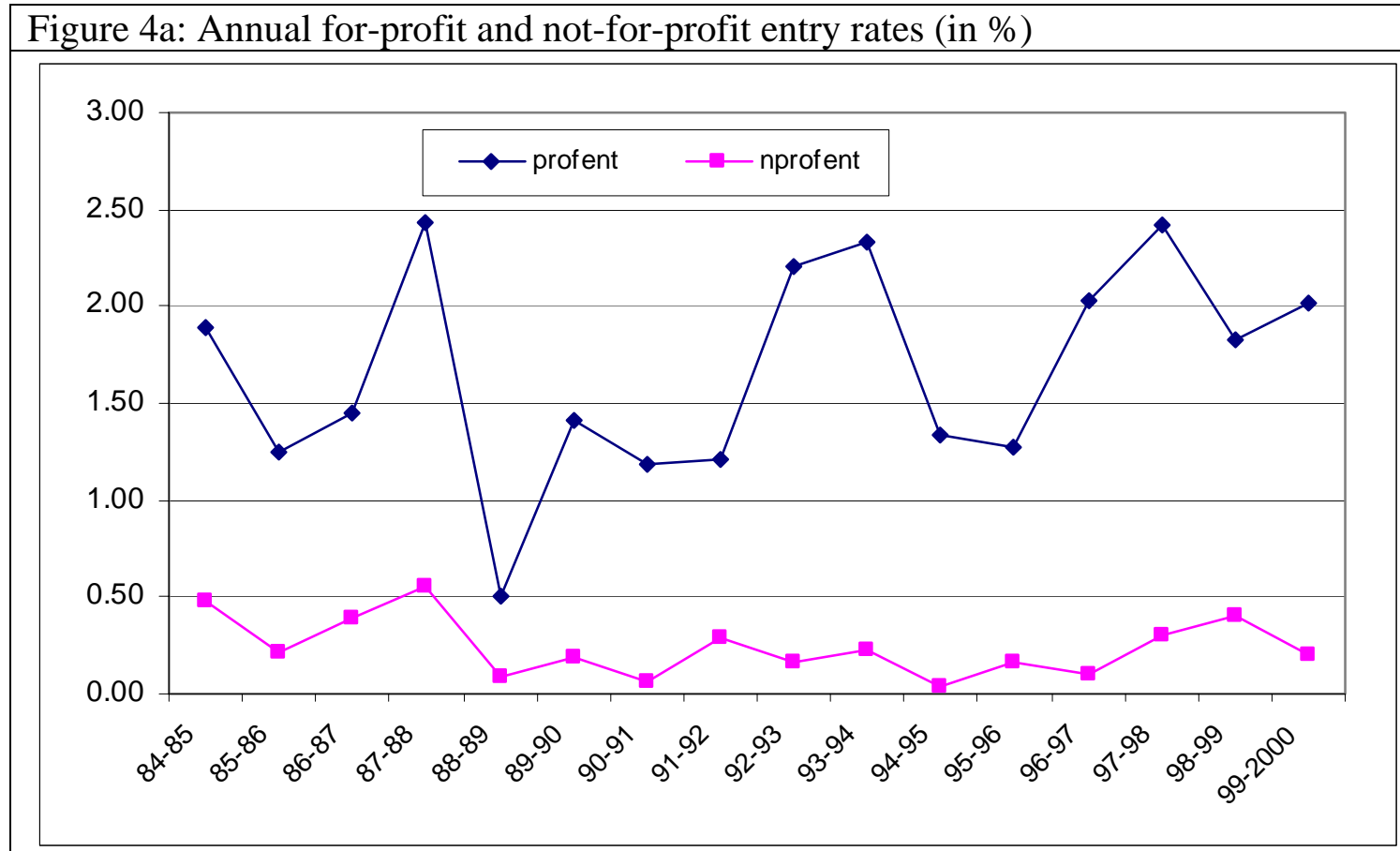

Figure 4b: Annual for-profit and not-for-profit exit rates (in \%)

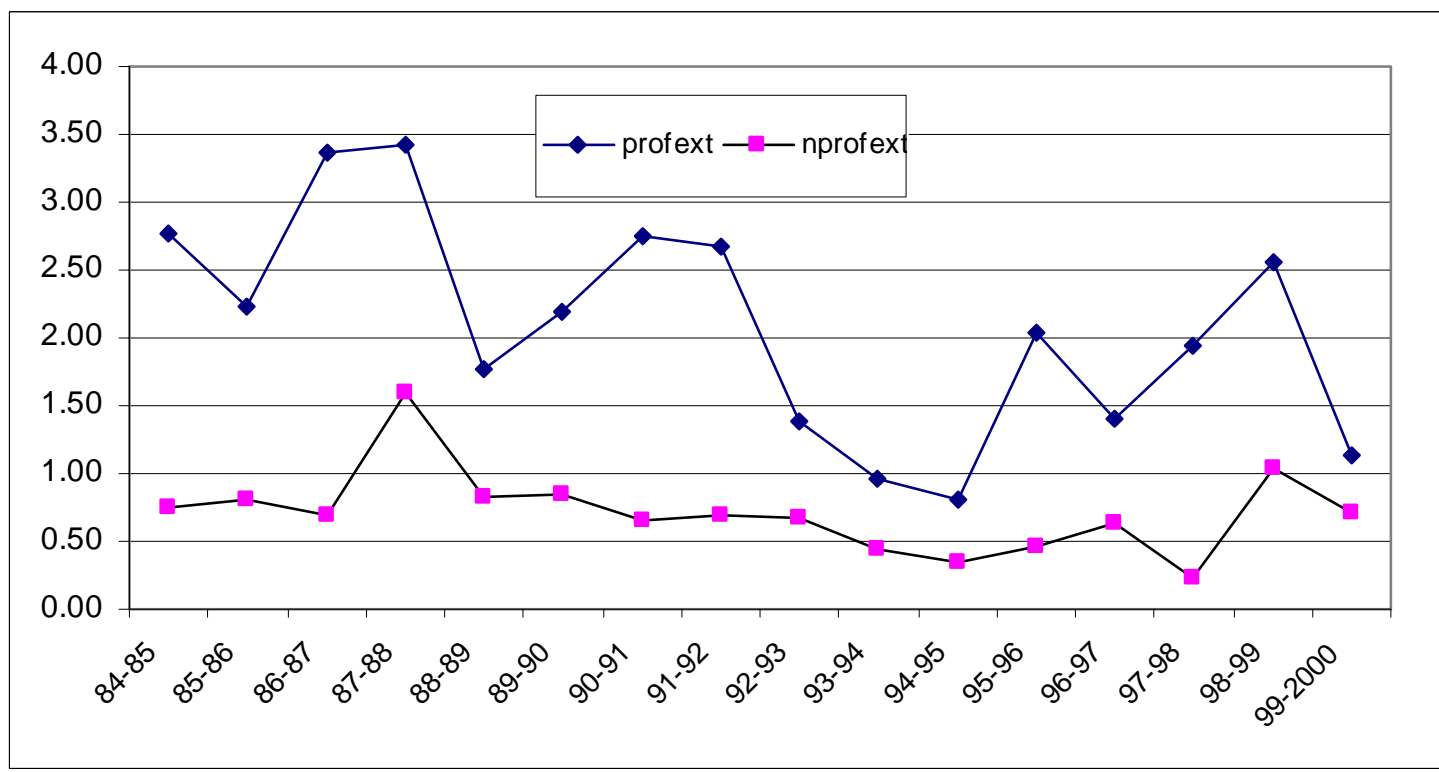


Table I. No. of hospital establishments

\begin{tabular}{|c|c|c|c|c|}
\hline & Public & Not-for-profit & For-profit & Total \\
\hline 1970 & 1618 & 3332 & 746 & 5696 \\
\hline 1972 & 1695 & 3279 & 704 & 5678 \\
\hline 1974 & 1731 & 3334 & 739 & 5804 \\
\hline 1976 & 1743 & 3318 & 717 & 5778 \\
\hline 1978 & 1792 & 3340 & 757 & 5889 \\
\hline 1980 & 1783 & 3302 & 715 & 5800 \\
\hline 1982 & 1716 & 3312 & 756 & 5784 \\
\hline 1984 & 1618 & 3326 & 795 & 5739 \\
\hline 1985 & 1573 & 3326 & 805 & 5704 \\
\hline 1986 & 1518 & 3301 & 830 & 5649 \\
\hline 1987 & 1502 & 3260 & 820 & 5582 \\
\hline 1988 & 1491 & 3229 & 794 & 5514 \\
\hline 1989 & 1458 & 3209 & 778 & 5445 \\
\hline 1990 & 1438 & 3177 & 762 & 5377 \\
\hline 1991 & 1420 & 3153 & 746 & 5319 \\
\hline 1992 & 1386 & 3148 & 727 & 5261 \\
\hline 1993 & 1380 & 3127 & 730 & 5237 \\
\hline 1994 & 1360 & 3103 & 746 & 5209 \\
\hline 1995 & 1334 & 3056 & 784 & 5174 \\
\hline 1996 & 1315 & 3008 & 788 & 5111 \\
\hline 1997 & 1251 & 2970 & 825 & 5046 \\
\hline 1998 & 1205 & 2994 & 823 & 5022 \\
\hline 1999 & 1188 & 2991 & 794 & 4973 \\
\hline 2000 & 1153 & 2999 & 802 & 4954 \\
\hline 2001 & 1150 & 2981 & 800 & 4931 \\
\hline \% change over (1970-2000) & -28.92 & -10.53 & 7.24 & -13.43 \\
\hline
\end{tabular}


Table 2a Percentage changes in output, capacity and no. of establishments

\begin{tabular}{|lllllll|}
\hline & \multicolumn{3}{c}{ \% change over 1970-1985 } & \multicolumn{3}{c|}{ \% change over 1985-2000 } \\
& No. of estb. & Beds & Inpatient Days & No. of estb. & beds & Inpatient Days \\
\hline Public & -7.2 & -12.1 & -25.1 & -26.7 & -35.9 & -37.2 \\
Not-for-profit & 1.4 & 10.8 & -4.3 & -9.8 & -21.1 & -24.7 \\
For-profit & 14.3 & 85.7 & 41.0 & -0.4 & 5.2 & 12.6 \\
\hline
\end{tabular}

Table $2 \mathrm{~b}$ Change in proportion of output, capacity and no. of establishments

\begin{tabular}{|lllllll|}
\hline & \multicolumn{3}{c}{ Share in 1985 (\% terms) } & \multicolumn{3}{c|}{ Share in 2000 (\% terms) } \\
& No. of estb. & Beds & Inpatient Days & No. of estb. & beds & Inpatient Days \\
\hline Public & 27.6 & 18.2 & 17.2 & 23.3 & 14.7 & 14.1 \\
Not-for-profit & 58.3 & 71.0 & 74.0 & 60.5 & 70.8 & 73.0 \\
For-profit & 14.1 & 10.8 & 8.8 & 16.2 & 14.4 & 12.9 \\
\hline
\end{tabular}


Table 3: $\quad$ Entry and exit of For-profit and Not-for-profit hospitals

\begin{tabular}{|c|c|c|c|c|c|c|c|c|c|c|}
\hline & \multicolumn{4}{|c|}{ Entries } & \multicolumn{4}{|c|}{ Exits } & \multicolumn{2}{|c|}{ Incumbents } \\
\hline & \multicolumn{2}{|c|}{ For-profit } & \multicolumn{2}{|c|}{ Not-for-profit } & \multicolumn{2}{|c|}{ For-profit } & \multicolumn{2}{|c|}{ Not-for-profit } & For-profit & Not-for-profit \\
\hline 1984 & 23 & & 17 & & 22 & & 25 & & 795 & 3326 \\
\hline 1985 & 15 & $(1.89)$ & 16 & $(0.48)$ & 18 & $(2.77)$ & 27 & $(0.75)$ & 805 & 3326 \\
\hline 1986 & 10 & $(1.24)$ & 7 & $(0.21)$ & 28 & $(2.24)$ & 23 & $(0.81)$ & 830 & 3301 \\
\hline 1987 & 12 & (1.45) & 13 & $(0.39)$ & 28 & (3.37) & 52 & $(0.70)$ & 820 & 3260 \\
\hline 1988 & 20 & (2.44) & 18 & $(0.55)$ & 14 & (3.41) & 27 & $(1.60)$ & 794 & 3229 \\
\hline 1989 & 4 & $(0.50)$ & 3 & $(0.09)$ & 17 & $(1.76)$ & 27 & $(0.84)$ & 778 & 3209 \\
\hline 1990 & 11 & (1.41) & 6 & $(0.19)$ & 21 & (2.19) & 21 & $(0.84)$ & 762 & 3177 \\
\hline 1991 & 9 & (1.18) & 2 & $(0.06)$ & 20 & $(2.76)$ & 22 & $(0.66)$ & 746 & 3153 \\
\hline 1992 & 9 & $(1.21)$ & 9 & $(0.29)$ & 10 & (2.68) & 21 & $(0.70)$ & 727 & 3148 \\
\hline 1993 & 16 & $(2.20)$ & 5 & $(0.16)$ & 7 & $(1.38)$ & 14 & $(0.67)$ & 730 & 3127 \\
\hline 1994 & 17 & (2.33) & 7 & $(0.22)$ & 6 & $(0.96)$ & 11 & $(0.45)$ & 746 & 3103 \\
\hline 1995 & 10 & (1.34) & 1 & $(0.03)$ & 16 & $(0.80)$ & 14 & $(0.35)$ & 784 & 3056 \\
\hline 1996 & 10 & $(1.28)$ & 5 & $(0.16)$ & 11 & (2.04) & 19 & $(0.46)$ & 788 & 3008 \\
\hline 1997 & 16 & $(2.03)$ & 3 & $(0.10)$ & 16 & $(1.40)$ & 7 & $(0.63)$ & 825 & 2970 \\
\hline 1998 & 20 & $(2.42)$ & 9 & $(0.30)$ & 21 & (1.94) & 31 & $(0.24)$ & 823 & 2994 \\
\hline 1999 & 15 & $(1.82)$ & 12 & $(0.40)$ & 9 & $(2.55)$ & 21 & (1.04) & 794 & 2991 \\
\hline 2000 & 16 & $(2.02)$ & 6 & $(0.20)$ & 8 & $(1.13)$ & 25 & $(0.70)$ & 802 & 2999 \\
\hline Total & 233 & (1.75) & 139 & $(0.26)$ & 272 & $(2.04)$ & 387 & $(0.73)$ & & \\
\hline
\end{tabular}

Note: Numbers within parenthesis denote percentage rates of entry and exit 
Table 4: Comparing Exit Rates of Entrants and Incumbents

\begin{tabular}{|c|c|c|c|c|c|c|}
\hline & $\begin{array}{l}\text { Incumbents } \\
\text { in } 1984\end{array}$ & $\begin{array}{l}\text { Exiters out of } \\
1984 \text { incumbents }\end{array}$ & $\begin{array}{l}\text { exit rate of } \\
\text { incumbents }\end{array}$ & $\begin{array}{l}\text { entrants } \\
\text { over 1984- } \\
2000\end{array}$ & $\begin{array}{l}\text { entrants who } \\
\text { exited }\end{array}$ & $\begin{array}{l}\text { exit rate of } \\
\text { entrants }\end{array}$ \\
\hline Public & 1618 & 180 & 11.1 & 29 & 4 & 13.8 \\
\hline non-profit & 3326 & 340 & 10.2 & 139 & 15 & 10.8 \\
\hline for-profit & 795 & 222 & 27.9 & 233 & 26 & 11.2 \\
\hline Total & 5739 & 742 & 12.9 & 401 & 45 & 11.2 \\
\hline
\end{tabular}


Table 5 : Entry and exit of hospitals at the census division level over 1984-2000

\begin{tabular}{|l|r|r|r|r|r|r|r|r|r|r|}
\hline Division & \multicolumn{2}{|l|}{ hospitals in 84 } & \multicolumn{2}{l|}{ Entries: 84-00 } & \multicolumn{2}{l|}{ Exits: 84-00 } & \multicolumn{2}{l|}{ Entry Rates } & \multicolumn{2}{l|}{ Exit Rates } \\
\hline & FP & NFP & FP & NFP & FP & NFP & FP & NFP & FP & NFP \\
\hline New England & 3 & 227 & 5 & 3 & 0 & 22 & 167 & 1 & 0 & 10 \\
\hline Mid Atlantic & 32 & 527 & 5 & 6 & 16 & 41 & 16 & 1 & 50 & 8 \\
\hline East North Central & 14 & 695 & 8 & 6 & 7 & 86 & 57 & 1 & 50 & 12 \\
\hline West North Central & 35 & 450 & 18 & 17 & 15 & 51 & 51 & 4 & 43 & 11 \\
\hline South Atlantic & 179 & 421 & 34 & 21 & 38 & 43 & 19 & 5 & 21 & 10 \\
\hline East South Central & 124 & 183 & 16 & 6 & 25 & 30 & 13 & 3 & 20 & 16 \\
\hline West South Central & 217 & 276 & 110 & 36 & 94 & 57 & 51 & 13 & 43 & 21 \\
\hline Mountain & 35 & 208 & 19 & 18 & 16 & 23 & 54 & 9 & 46 & 11 \\
\hline Pacific & 156 & 339 & 18 & 26 & 61 & 34 & 12 & 8 & 39 & 10 \\
\hline
\end{tabular}

Note: The totals in 1984 and 2000 do not tally with entry and exit since these also include conversions; FP refers to for-profit hospitals and NFP refers to not-for-profit hospitals. Rates calculated over the same time period 
Table 6: Predictors of log change in hospital capacity in a HSA

\begin{tabular}{|l|r|r|r|}
\hline Variable & \multicolumn{1}{l|}{ loefficient } & \multicolumn{1}{l|}{ Std Error } & P value \\
\hline & & & \\
\hline Intercept & -0.384 & 0.037 & 0.000 \\
\hline Lnpopgrowth & 0.089 & 0.080 & 0.262 \\
\hline Inelderlypopgrowth & 0.390 & 0.078 & 0.000 \\
\hline Inpop70 & -0.223 & 0.113 & 0.049 \\
\hline Inpop80 & 0.235 & 0.115 & 0.042 \\
\hline div1 & -0.125 & 0.059 & 0.035 \\
\hline div2 & 0.051 & 0.047 & 0.280 \\
\hline div3 & -0.117 & 0.035 & 0.001 \\
\hline div5 & 0.083 & 0.039 & 0.033 \\
\hline div6 & 0.183 & 0.039 & 0.000 \\
\hline div7 & 0.059 & 0.034 & 0.084 \\
\hline div8 & -0.001 & 0.042 & 0.980 \\
\hline div9 & -0.010 & 0.048 & 0.831 \\
\hline Con law & -0.061 & 0.025 & 0.016 \\
\hline
\end{tabular}

Note:

1. Adj. R-Sq 0.29

2. obs $=800$

3. growth rates are taken over 1980-2000 
Table 7: Summary Statistics at county level

\begin{tabular}{|lrr|}
\hline & Mean & Standard Deviation \\
For-profit entry & 0.08 & 0.49 \\
Not-for-profit entry & 0.05 & 0.29 \\
For-profit exit & 0.09 & 0.74 \\
Not-for-profit exit & 0.13 & 0.58 \\
pop70 & 65786.55 & 230869.60 \\
pop80 & 73308.18 & 238386.50 \\
pop00 & 91013.37 & 295386.50 \\
Inpop80 & 10.12 & 1.32 \\
Popgrowth & 17.63 & 37.08 \\
Logpopgrowth & 0.13 & 0.26 \\
aged70 & 6834.16 & 22284.65 \\
aged80 & 8288.13 & 26153.30 \\
aged00 & 11324.72 & 32998.45 \\
Elderlypopgrowth & 33.72 & 47.03 \\
Ln elderlypopgrowth & 0.25 & 0.28 \\
Logagedgr70 & 0.17 & 0.10 \\
Proportion of elderly80 & 0.13 & 0.04 \\
Proportion of elderly00 & 0.14 & 0.04 \\
Pcy80 & 7716.14 & 1788.58 \\
Pcy96 & 19114.34 & 4519.51 \\
Inage80 & 8.05 & 1.23 \\
Logpcy80 & 8.92 & 0.23 \\
Lnwage80 & 0.83 & 0.21 \\
Lnwagegrowth & 9.02 & 0.13 \\
Not:No & 0.05 \\
\hline
\end{tabular}

Note: No. of observations is 3070 
Table: 8 Ordered Probit estimation of hospital entry in a county

\begin{tabular}{|c|c|c|c|c|c|c|}
\hline & \multicolumn{3}{|c|}{ For-profit hospital } & \multicolumn{3}{|c|}{ Not-for-profit hospital } \\
\hline & coefficient & std. error & $p$ value & Coefficient & std. error & $\mathrm{p}$ value \\
\hline Log elderlypopgrowth & 1.140 & 0.227 & 0.000 & 0.394 & 0.240 & 0.100 \\
\hline Inpop80 & 0.794 & 0.063 & 0.000 & 0.574 & 0.059 & 0.000 \\
\hline Inpropelderlypop80 & 0.296 & 0.175 & 0.092 & 0.373 & 0.194 & 0.055 \\
\hline Inpcy80 & 0.043 & 0.345 & 0.900 & 0.594 & 0.367 & 0.106 \\
\hline Logpcygrowth & -0.665 & 0.349 & 0.057 & 0.139 & 0.350 & 0.691 \\
\hline Lnwage80 & -1.699 & 0.701 & 0.015 & 0.187 & 0.709 & 0.792 \\
\hline Lnwagegr & -2.719 & 1.090 & 0.013 & -2.501 & 1.129 & 0.027 \\
\hline Con & -0.205 & 0.159 & 0.199 & -0.222 & 0.160 & 0.164 \\
\hline $\operatorname{div} 1$ & -0.226 & 0.347 & 0.515 & -0.732 & 0.379 & 0.053 \\
\hline $\operatorname{div} 2$ & -1.010 & 0.314 & 0.001 & -1.085 & 0.318 & 0.001 \\
\hline $\operatorname{div} 3$ & -0.789 & 0.262 & 0.003 & -0.912 & 0.266 & 0.001 \\
\hline $\operatorname{div} 5$ & -0.071 & 0.225 & 0.754 & -0.255 & 0.233 & 0.275 \\
\hline $\operatorname{div} 6$ & 0.177 & 0.241 & 0.462 & -0.117 & 0.273 & 0.670 \\
\hline $\operatorname{div} 7$ & 0.514 & 0.198 & 0.009 & 0.255 & 0.197 & 0.195 \\
\hline $\operatorname{div} 8$ & -0.181 & 0.267 & 0.498 & -0.023 & 0.252 & 0.927 \\
\hline $\operatorname{div} 9$ & -0.508 & 0.299 & 0.090 & -0.223 & 0.268 & 0.406 \\
\hline LR Chi square & 480.75 & & & 351.10 & & \\
\hline Log Likelihood & -435.15 & & & -347.75 & & \\
\hline No of Observations & 3070 & & & 3070 & & \\
\hline
\end{tabular}


Table 9 Exit rates across different quartiles of population growth

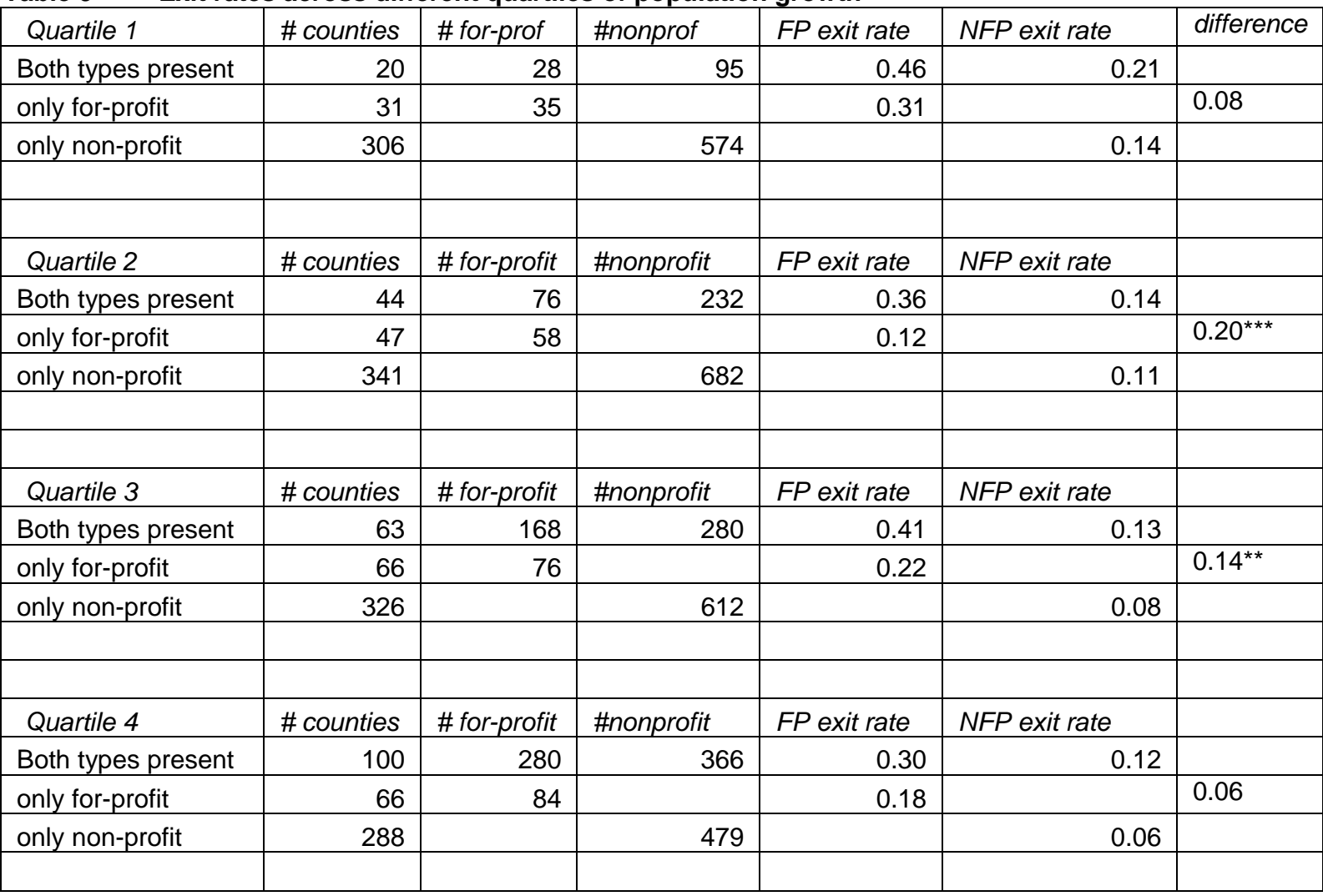

\section{Note:}

Exit rates are calculated by dividing no. of exits by no. of hospitals in the base year

Quartiles 1-4 denote an ascending order in terms of population growth

* denotes $10 \%$ level of significance

** denotes $5 \%$ level of significance

${ }^{* * *}$ denotes $1 \%$ level of significance 
Table 10 Exit rates across different quartiles of elderly population growth

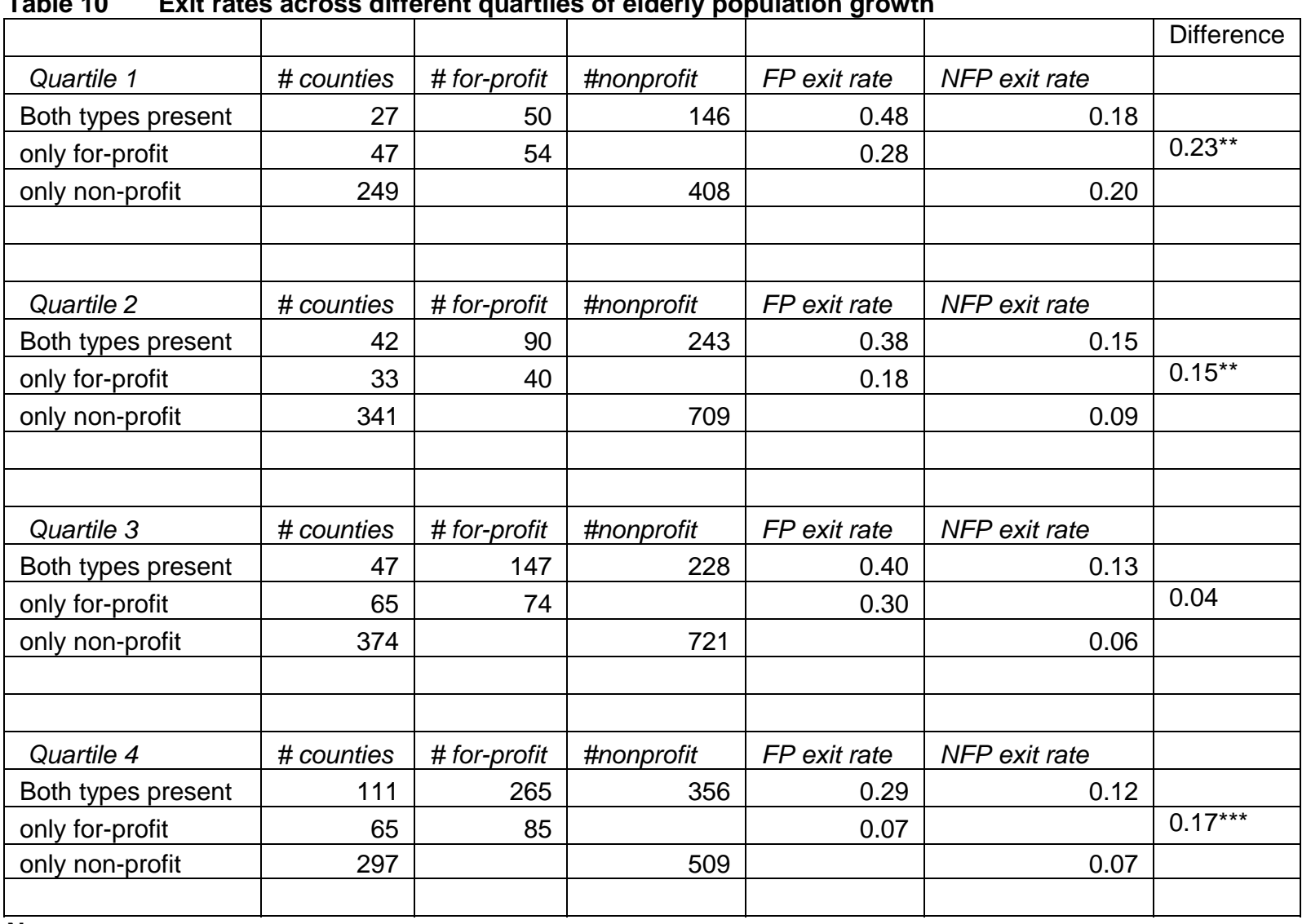

\section{Note:}

Exit rates are calculated by dividing no. of exits by no. of hospitals in the base year

Quartiles 1-4 denote an ascending order in terms of population growth

* denotes $10 \%$ level of significance

** denotes $5 \%$ level of significance

${ }^{* \star *}$ denotes $1 \%$ level of significance 
Table 11 Summary Statistics for exit estimation

\begin{tabular}{|lrr|}
\hline & mean & Standard deviation \\
Exit & 0.01 & 0.12 \\
pop80 & 1479362.00 & 2092282.00 \\
pop00 & 1873384.00 & 2576215.00 \\
aged80 & 154878.50 & 212309.60 \\
aged00 & 201579.40 & 255857.40 \\
Exit & 0.01 & 0.12 \\
System & 0.66 & 0.47 \\
pcy00 & 25454.21 & 6094.43 \\
pcy80 & 10116.62 & 1822.70 \\
wage91 & 10127.54 & 1564.16 \\
wage01 & 10104.23 & 1605.76 \\
Inpop80 & 13.33 & 1.40 \\
Ln elderlypopgrowth & 0.36 & 0.26 \\
Prop. Aged & 0.11 & 0.04 \\
Ln propaged & -2.24 & 0.31 \\
Lnpopgrowth & 0.26 & 0.24 \\
Inpcy80 & 9.20 & 0.19 \\
Lnpcygrowth & 0.78 & 0.18 \\
Lnwage80 & 9.21 & 0.15 \\
Lnwagegrowth & 0.002 & 0.05 \\
No. of observations 22818 & & \\
\hline Note: Our dependent 2 . & & \\
\hline
\end{tabular}

Note: Our dependent variable is exit which can be 0 or 1 
Table 12 Marginal effects on probability of hospital exit (for-profit and not-for-profit)

\begin{tabular}{|c|c|c|c|c|c|c|}
\hline \multirow[b]{2}{*}{ Variable } & \multicolumn{3}{|c|}{ For-profit exit } & \multicolumn{3}{|c|}{ Not-for-profit exit } \\
\hline & Marginal effect & Std. Err. & $\mathrm{p}$ value & Marginal effect & Std. Err. & $\mathrm{p}$ value \\
\hline Ln propelderlypop80 & 0.005 & 0.005 & 0.328 & -0.005 & 0.003 & 0.142 \\
\hline Ln pop80 & 0.002 & 0.001 & 0.099 & 0.001 & 0.001 & 0.430 \\
\hline Ln elderlypopgrowth & -0.017 & 0.006 & 0.003 & -0.008 & 0.004 & 0.031 \\
\hline System Membership & -0.050 & 0.007 & 0.000 & 0.000 & 0.001 & 0.693 \\
\hline Con law & 0.004 & 0.003 & 0.280 & 0.003 & 0.002 & 0.222 \\
\hline Lnwg80 & -0.004 & 0.016 & 0.795 & -0.002 & 0.009 & 0.805 \\
\hline Lnwagegrowth & 0.043 & 0.025 & 0.085 & 0.023 & 0.012 & 0.062 \\
\hline Lnpcy80 & -0.005 & 0.007 & 0.452 & 0.002 & 0.005 & 0.729 \\
\hline Lnpcyrgrowth & 0.014 & 0.007 & 0.044 & 0.000 & 0.004 & 0.962 \\
\hline Div2* & -0.009 & 0.004 & 0.012 & -0.003 & 0.003 & 0.193 \\
\hline Div3* & -0.009 & 0.003 & 0.003 & -0.001 & 0.003 & 0.712 \\
\hline Div5* & -0.011 & 0.004 & 0.012 & 0.000 & 0.003 & 0.950 \\
\hline Div6* & -0.007 & 0.004 & 0.068 & 0.000 & 0.003 & 0.983 \\
\hline Div7* & 0.004 & 0.007 & 0.500 & 0.004 & 0.004 & 0.359 \\
\hline Div8* & 0.017 & 0.015 & 0.253 & 0.003 & 0.005 & 0.606 \\
\hline Div9* & 0.000 & 0.007 & 0.955 & 0.001 & 0.004 & 0.895 \\
\hline Year85* & 0.008 & 0.010 & 0.414 & 0.001 & 0.003 & 0.746 \\
\hline Year86* & 0.022 & 0.014 & 0.125 & -0.002 & 0.003 & 0.471 \\
\hline Year87* & 0.013 & 0.011 & 0.242 & 0.008 & 0.005 & 0.121 \\
\hline Year88* & 0.006 & 0.008 & 0.452 & -0.001 & 0.003 & 0.562 \\
\hline Year89* & 0.009 & 0.010 & 0.408 & 0.001 & 0.003 & 0.838 \\
\hline Year90* & 0.015 & 0.010 & 0.165 & -0.002 & 0.002 & 0.359 \\
\hline Year91* & 0.013 & 0.010 & 0.203 & -0.003 & 0.002 & 0.211 \\
\hline Year92* & 0.001 & 0.007 & 0.906 & -0.002 & 0.002 & 0.382 \\
\hline Year93* & -0.005 & 0.005 & 0.338 & -0.003 & 0.002 & 0.181 \\
\hline Year94* & -0.005 & 0.006 & 0.401 & -0.001 & 0.003 & 0.798 \\
\hline Year95* & 0.009 & 0.011 & 0.419 & -0.004 & 0.002 & 0.020 \\
\hline Year96* & 0.006 & 0.009 & 0.505 & -0.001 & 0.003 & 0.644 \\
\hline Year97* & 0.015 & 0.011 & 0.188 & -0.006 & 0.001 & 0.000 \\
\hline Year98* & 0.016 & 0.012 & 0.188 & 0.002 & 0.003 & 0.634 \\
\hline Year99* & 0.005 & 0.010 & 0.608 & 0.001 & 0.004 & 0.828 \\
\hline No. of Observations & 8664 & & & 14154 & & \\
\hline Wald chi square & 244.27 & & & 117.91 & & \\
\hline
\end{tabular}


Table 13 Out of sample prediction of effect sizes of population growth

\begin{tabular}{|c|c|c|c|c|c|}
\hline $\begin{array}{l}\text { Prediction } \\
\text { sample }\end{array}$ & \multicolumn{2}{|c|}{ For-profit hospital model } & \multicolumn{2}{|c|}{ Not-for-profit hospital model } & Difference \\
\hline & $\begin{array}{l}\text { Exit } \\
\text { Probability }\end{array}$ & Marginal Effect & Exit Probability & $\begin{array}{l}\text { Marginal } \\
\text { Effect }\end{array}$ & $\begin{array}{l}\text { Marginal } \\
\text { effects }\end{array}$ \\
\hline FP sample & 0.022 & $-0.027^{\star \star \star}$ & 0.008 & $-0.010 * *$ & $0.017^{*}$ \\
\hline NFP sample & 0.037 & $-0.043^{\star \star \star}$ & 0.008 & $-0.010^{\star \star}$ & $0.023^{\star \star}$ \\
\hline Whole sample & 0.031 & $-0.037^{\star \star \star}$ & 0.008 & $-0.010 * *$ & $0.027^{\star *}$ \\
\hline
\end{tabular}

Note :

Standard errors calculated by delta method

* significant at $10 \%$ level

** significant at $5 \%$ level

*** significant at $1 \%$ level 
Table 14 : Comparing marginal Effects when public hospitals are also included

\begin{tabular}{|c|c|c|c|c|c|c|}
\hline & For-profit (I) & Not-for-profit (I) & Public(I) & For-profit (II) & Not-for-profit (II) & Public(II) \\
\hline \multirow[t]{2}{*}{ Inpropelderlypop80 } & -0.0027 & 0.0012 & -0.0001 & -0.0014 & -0.0060 & 0.0038 \\
\hline & $(0.0094)$ & $(0.0032)$ & $(0.0048)$ & $(0.0078)$ & $(0.0047)$ & $(0.0048)$ \\
\hline \multirow[t]{2}{*}{ Inpop80 } & 0.0004 & $0.0017^{*}$ & -0.0021 & 0.0000 & 0.0015 & -0.0010 \\
\hline & $(0.0020)$ & $(0.0009)$ & $(0.0022)$ & $(0.0022)$ & $(0.0011)$ & $(0.0019)$ \\
\hline \multirow[t]{2}{*}{ Log elderlypopgrowth } & $-0.0181^{*}$ & 0.0048 & -0.0004 & $-0.0140^{*}$ & 0.0014 & -0.0011 \\
\hline & $(0.0106)$ & $(0.0034)$ & $(0.0065)$ & $(0.0085)$ & $(0.0039)$ & $(0.0053)$ \\
\hline \multirow[t]{2}{*}{ System membership } & $-0.0416^{\star \star \star}$ & 0.0002 & -0.0050 & $-0.0498^{\star \star \star}$ & -0.0014 & $-0.0062^{*}$ \\
\hline & $(0.0065)$ & $(0.0014)$ & $(0.0032)$ & $(0.0088)$ & $(0.0015)$ & $(0.0032)$ \\
\hline \multirow[t]{2}{*}{ CON Law } & -0.0035 & -0.0016 & -0.0003 & $-0.0115^{\star *}$ & -0.0018 & 0.0046 \\
\hline & $(0.0052)$ & $(0.0025)$ & $(0.0036)$ & $(0.0055)$ & $(0.0029)$ & $(0.0036)$ \\
\hline \multirow[t]{2}{*}{ Lnwage80 } & -0.0320 & -0.0155 & -0.0225 & -0.0307 & -0.0146 & -0.0062 \\
\hline & (0.0298) & $(0.0115)$ & $(0.0201)$ & (0.0309) & $(0.0122)$ & $(0.0196)$ \\
\hline \multirow[t]{2}{*}{ Lnwagegrowth } & 0.0653 & 0.0680 *** & -0.0054 & $0.0909 * *$ & $0.0548 * \star \star$ & -0.0022 \\
\hline & $(0.0418)$ & $(0.0145)$ & $(0.0335)$ & $(0.0394)$ & (0.0195) & $(0.0313)$ \\
\hline \multirow[t]{2}{*}{ Inpcy80 } & 0.0171 & 0.0074 & 0.0103 & 0.0119 & 0.0052 & -0.0037 \\
\hline & $(0.0132)$ & $(0.0056)$ & (0.0118) & $(0.0126)$ & $(0.0081)$ & $(0.0103)$ \\
\hline \multirow[t]{2}{*}{ Logpcygrowth } & $0.0264^{*}$ & 0.0078 & -0.0048 & 0.0133 & 0.0070 & -0.0039 \\
\hline & $(0.0143)$ & $(0.0037)$ & $(0.0077)$ & $(0.0158)$ & $(0.0047)$ & $(0.0079)$ \\
\hline No of observations & 3726 & 5298 & 1910 & 5543 & 9417 & 2777 \\
\hline Wald Chi Square & 144.02 & 122.29 & 121.57 & 105.59 & 33.80 & 21.92 \\
\hline
\end{tabular}

Note:

Standard errors are cluster corrected. Year and division dummies taken as controls for specification1. Only region dummies taken as controls for specification II

* denotes $10 \%$ level of significance

** denotes $5 \%$ level of significance

${ }^{\star * *}$ denotes $1 \%$ level of significance 
Table 15: Multinomial Logit: Marginal Effects on Probability of Hospital Exit

\begin{tabular}{|llll|}
\hline Variable & Public & Not-for-profit & For-profit \\
Inpropelderlypop80 & & & \\
& -0.0407 & -0.0237 & 0.06439 \\
Inpop80 & $(0.0424)$ & $(0.1885)$ & $(0.1783)$ \\
& $-0.0377^{\star \star \star}$ & 0.0229 & 0.01479 \\
Log elderlypopgrowth & $(0.0150)$ & $(0.0438)$ & $(0.0450)$ \\
& 0.0694 & $0.4514^{\star}$ & $-0.52078^{\star \star}$ \\
System membership & $(0.0580)$ & $(0.2411)$ & $(0.2331)$ \\
& $-0.0786^{\star \star}$ & 0.1147 & -0.03610 \\
Con law & $(0.0286)$ & $(0.0729)$ & $(0.0730)$ \\
& 0.0027 & $0.2269^{\star}$ & $-0.22966^{\star}$ \\
Lnwage80 & $(0.0469)$ & $(0.1197)$ & $(0.1345)$ \\
& 0.0116 & -0.0572 & 0.04561 \\
Lnwagegrowth & $(0.1077)$ & $(0.3452)$ & $(0.3571)$ \\
& -0.2330 & $1.7711^{\star \star \star}$ & $-1.53812^{\star \star \star}$ \\
Lnpcy80 & $(0.2474)$ & $(0.5380)$ & $(0.5917)$ \\
& 0.0777 & 0.0410 & -0.11869 \\
Lnpcygrowth & $(0.0861)$ & $(0.2353)$ & $(0.2395)$ \\
& $-0.1818^{\star *}$ & $0.4949^{\star *}$ & -0.31314 \\
Probability of Exit & $(0.0825)$ & $(0.2506)$ & $(0.2763)$ \\
Wald Chi Square & 0.035 & 0.258 & 0.707 \\
No. of Observations & 166.76 & & \\
\end{tabular}

Note:

Standard errors are cluster corrected. Division dummies have been taken as controls. Exits, in only those county years that had all3

types of hospitals, were considered. In this sample of hospitals, there were no for-profit exits in division 1, and no public hospital exits in divisions 1,3 , and 8.

* denotes $10 \%$ level of significance

** denotes $5 \%$ level of significance

${ }^{* *}$ denotes $1 \%$ level of significance 


\section{Appendix: Variables}

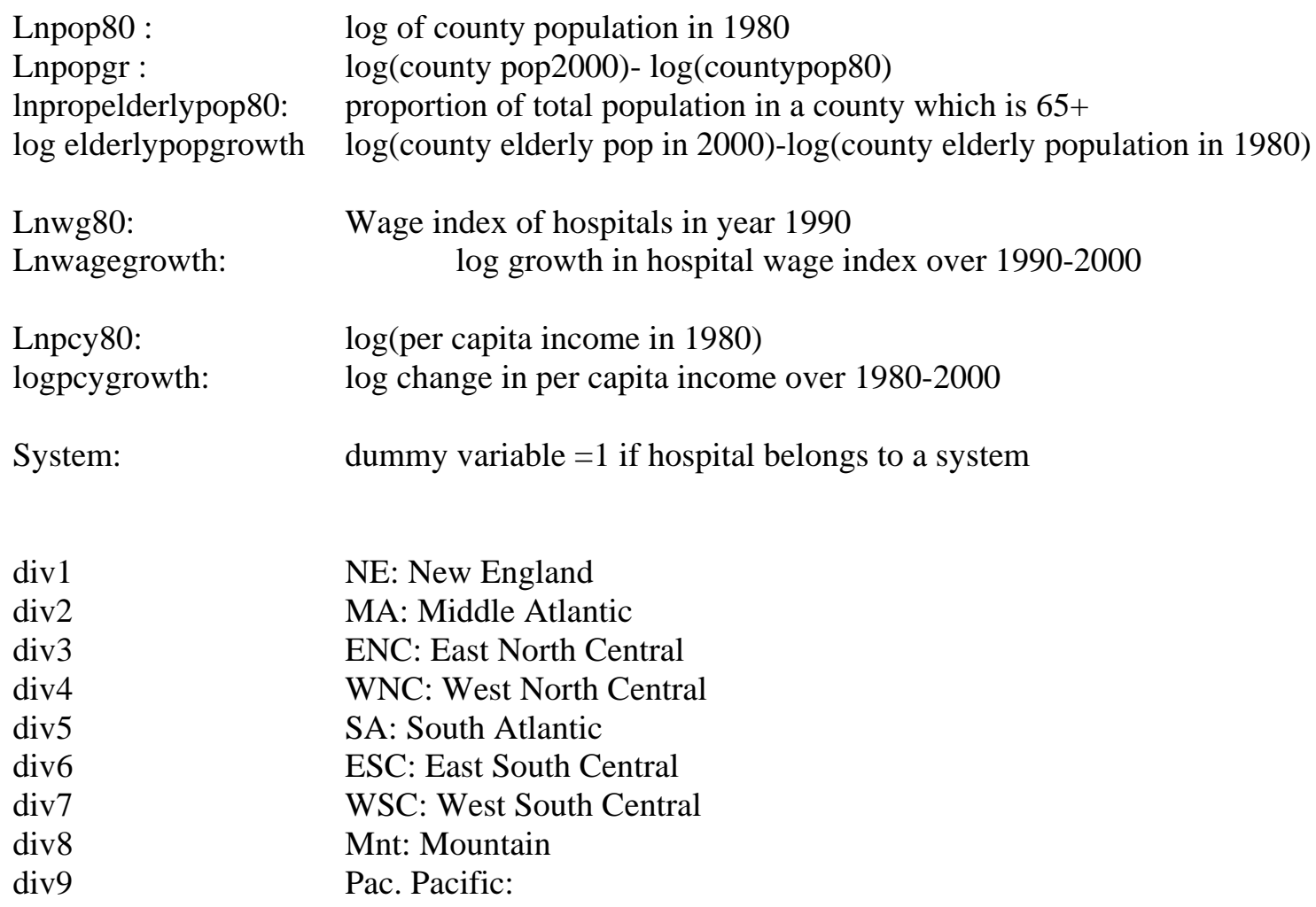

